\title{
Microcleidus melusinae, a new plesiosaurian (Reptilia, Plesiosauria) from the Toarcian of Luxembourg
}

\author{
PEGGY VINCENT ${ }^{*} \dagger$, ROBERT WEIS $\$$, GUY KRONZ $\$ \&$ DOMINIQUE DELSATE $\ddagger$ \\ *CR2P, CNRS-MNHN-UPMC, Département Histoire de la Terre, Muséum national d'histoire naturelle,
}

CP 38, 57 rue Cuvier, F-75005, Paris, France

$\$$ Musée national d'histoire naturelle, Centre de recherche scientifique, Section Paléontologie,

25 rue Münster, L-2160 Luxembourg, Grand-Duché de Luxembourg

\begin{abstract}
Most of the known and most-complete Early Jurassic specimens of plesiosaurians were recovered from the United Kingdom and Germany, and few specimens from that age originate from other areas in Europe. This study describes a new plesiosaurian taxon from Toarcian deposits of Luxembourg, Microcleidus melusinae, represented by the most complete skeleton ever discovered from this country. A preliminary phylogenetic analysis places Microcleidus melusinae within Microcleididae, as a sister taxon of the species previously included in the genus Microcleidus. The new specimen studied here contributes to our understanding of the palaeodiversity of Early Jurassic plesiosaurians and confirms their high degree of 'endemism' and low morphological disparity.
\end{abstract}

Keywords: Jurassic, Luxembourg, Microcleidus, Microcleididae, Plesiosauria, Toarcian

\section{Introduction}

Plesiosaurians form a group of successful marine tetrapods secondarily adapted to an aquatic way of life whose stratigraphic range is Upper Triassic to uppermost Cretaceous (Bardet, 1992; Taylor \& Cruickshank, 1993a; Gasparini, Salgado \& Casad1o, 2003; Benson et al. 2009; Sennikov \& Arkhangelsky, 2010; Vincent et al. 2011). Most of the known and most-complete Early Jurassic specimens have been recovered from the United Kingdom and Germany (e.g. Benton \& Taylor, 1984; Urlichs, Wild \& Ziegler, 1994; Storrs, 1997; Großmann, 2007; Benson, Evans \& Druckenmiller, 2012; Vincent \& Benson, 2012; Sachs et al. 2016). A few specimens from that age are from other areas in Europe: France, Spain, Portugal, Luxembourg and Denmark (e.g. Godefroit, 1994; Rees \& Bonde, 1999; Bardet, Pereda Suberbiola \& Ruiz-Omeñaca, 2008; Smith, 2008; Smith, Araújo \& Mateus, 2012; Vincent, Bardet \& Mattioli, 2013), whereas they are cryptic in the rest of the world for this period (e.g. Thulborn \& Warren, 1980; Gasparini \& Fernandez, 1996; Kear, 2012). Most of the Early Jurassic plesiosaurian specimens were found and described during the nineteenth and early twentieth centuries (e.g. Owen, 1865; Dames, 1895). More recent discoveries are scarcer partly owing to the cessation of quarrying activity, which was prosperous during the early nineteenth century and exposed large areas for fossil hunting (e.g. the 'Lias' rock at Lyme Regis, UK). Still, field research, modern quarrying activities and construction works sometimes expose very interesting specimens (e.g. Schwermann \& Sander, 2011; Vincent et al. 2013;

†Author for correspondence: pvincent@mnhn.fr
Sachs, Schubert \& Kear, 2014). Here, we present a full description of one of them, a small-bodied specimen from the Lower Jurassic strata (Toarcian) of Luxembourg. It represents one of the rare plesiosaurian specimens from that stage found outside of the United Kingdom and Germany, and one of the rare plesiosaurian specimens from Luxembourg.

The Lower Jurassic strata, and especially the Toarcian strata, from Luxembourg, present a remarkable fauna of marine vertebrates, cephalopods and insects, that has been the subject of several publications in recent decades (Hanzo, 1978, 1979; Godefroit, 1994; Delsate \& Godefroit, 1995; Delsate 1997a,b, 1999a,b,c; Henrotay et al. 1998; Delsate \& Candoni, 2001; Delsate, 2003; Fuchs \& Weis, 2008; Delsate \& Weis, 2010; Hermoso et al. 2014; Szwedo, 2011). Lower Jurassic marine reptiles are mainly represented by specimens of Ichthyosauria (most of them belonging to the genus Stenopterygius; Godefroit, 1994; Maisch, 2008; Delsate \& Weis, 2010) and Thalattosuchia (most of them belonging to the genus Steneosaurus; Godefroit, 1994). Plesiosaurian specimens are represented by rare and partial remains (e.g. MNHNL TU797, a cervical vertebral centrum; MNHNL TU798, a tooth; Godefroit, 1994). Most of these remains come from the Toarcian strata and have been referred to the Elasmosauridae (Godefroit, 1994). However, the material is not complete and diagnostic enough to allow an infrafamilial systematic identification. The specimen described below is thus the first sub-complete plesiosaurian specimen discovered in this country. This paper assesses its systematic status and phylogenetic position based on detailed comparison with other Lower Jurassic plesiosauroid taxa. 
Institutional Abbreviations: GPIT - Institut für Geowissenschaften der Universität Tübingen, Tübingen, Germany; MB - Naturkundemuseum Berlin, Berlin, Germany; MNHNL - Musée national d'histoire naturelle de Luxembourg, Luxembourg; SMNS Staatliches Museum für Naturkunde, Stuttgart, Germany.

\section{History, geographical and stratigraphic setting}

The studied specimen (MNHNL TV434) was collected in the mid 1980s from construction works for electric pylons of the Pétange-Belval line, at almost equal distance from the localities of Sanem and Soleuvre (Fig. 1a), where the lower part of the Toarcian ('Couches à Harpoceras falciferum', $\mathrm{lo}_{1}$ on the geological map; Fig. 1b) crops out. It was recovered by the private collector René Hirtz (Soleuvre), and has not been accessible to scientific study until recently. The MNHNL acquired the specimen in 2013 and it has been extracted mechanically from the enclosing carbonate nodule by specialized preparator Oliver Kunze (Stuttgart, Germany). The specimen will be on permanent display at the MNHNL from 2017 onwards.

The carbonate nodule from which the specimen was extracted is similar to the numerous nodules present in the MNHNL collection from nearby localities, especially the Bascharage section, situated at c. $3.5 \mathrm{~km}$ from the locality where the plesiosaurian specimen (MNHNL TV434) was found. The fine lamination and dark grey colour of the clay originally attached laterally to the nodule is typical of the 'black shale' facies ('Schistes carton' of French authors) found in lower Toarcian successions of nearby areas (Hermoso et al. 2014). In addition, a crushed harpoceratid belonging to the Harpoceratinae subfamily, and diagnostic of the lower Toarcian (Andrea Di Cencio, pers. com. 2014), was found embedded on the outer part of the nodule enclosing the plesiosaurian specimen, and has been removed during the preparation process. Its state of preservation is insufficient to allow a precise ammonite zone assignment. It is, however, possible to further constrain the level from which the specimen was collected using previous descriptions of the stratigraphic successions of the area (Fig. 1; Hermoso et al. 2014).

According to the stratigraphic nomenclature and ammonite standard zonation commonly employed in northwestern Europe (e.g. Page, 2003), the lower Toarcian organic-rich black shales ('Couches à Harpoceras falciferum') can be referred to the Serpentinum Chronozone; lithostratigraphically, they are equivalent to the Schistes carton Fm in France, or to the Posidonienschiefer Fm in SW Germany. The black shales are best exposed at Bascharage (Bommelscheuer), where two discontinuous nodular levels (NOD1 and NOD2 in Henrotay et al. 1998) occur in the basal part (Exaratum Subchronozone; stratigraphic information after Hermoso et al. 2014). Similarly, in adja- cent areas, the basal part of this 'black shales' facies typically presents two nodular levels (Henrotay et al. 1998). The organic-rich succession also contains a conspicuous, $30 \mathrm{~cm}$ thick carbonate level, which occurs above the nodular levels and corresponds to the boundary between the Exaratum and the Falciferum subchronozones.

According to its characteristic shape and lithology, the nodule that yielded the plesiosaurian specimen can be referred either to the first or the second nodular level (NOD1 or NOD2 in Henrotay et al. 1998) occurring in the lower part of the black shale sequence, consistent with the ' $1 \mathrm{o}_{1}$ level' indicated in the geological map for the locality where the specimen was collected and which corresponds to the 'Couches à Harpoceras falciferum' (Serpentinum Chronozone) (Guérin-Franiatte, Maquil \& Münzberger, 2010). As notable nodular levels yielding vertebrate remains have been reported only from the Exaratum Subchronozone and not from the Falciferum Subchronozone (Hermoso et al. 2014), the specimen can thus be attributed to the Exaratum Subchronozone (Fig. 1b).

It is notable that the black shales of the basal lower Toarcian (Exaratum Subchronozone) have yielded numerous anatomically articulated fish and reptile specimens. The study of these specimens and enclosing strata give insight into the depositional conditions and taphonomy of the here-described specimen. Various levels of nodules or lenses at the base of the black shales are productive, as are the shales themselves. Vertebrates are either found in limestone (lenticular or nodular) or in shale beds; they can occur as complete, articulated skeletons (early burial) or as disarticulated remains (delayed burial), with or without necrotic bend or deformation. The vertebrate-yielding, finely laminated calcareous argillites and their nodules (strongly biconvex concretions) and 'lenses' (flat benches or very flattened nodules) were formed under anoxic to strongly dysoxic conditions (Hermoso et al. 2014). Hanzo (1979), in her study of the calcareous nodules from the paper shales of the Toarcian, recognized a very early diagenetic phase (presumably fast because of the good preservation of small ammonites and ostracods, compared to the preservation in the argillites) that likely affected a poorly consolidated, muddy sediment. It has been estimated that, after the first compaction phase affecting both the shales and still soft nodules, the second (post-nodular) compaction phase reduced their original thickness by as much as one-quarter. Hanzo (1978, 1979) has clearly shown that the formation of nodules at Bettembourg does not necessarily imply an emersion event, as hypothesized by Henrotay et al. (1998). Carbonate precipitation can be explained by local bacterial activity (see Thies, 1992; Plet et al. 2016) during the decomposition of bodies accumulated at the bottom of the sea in 'soupy' sediments (Martill, 1993), allowing corpses to be preserved in articulation and three dimensions. 


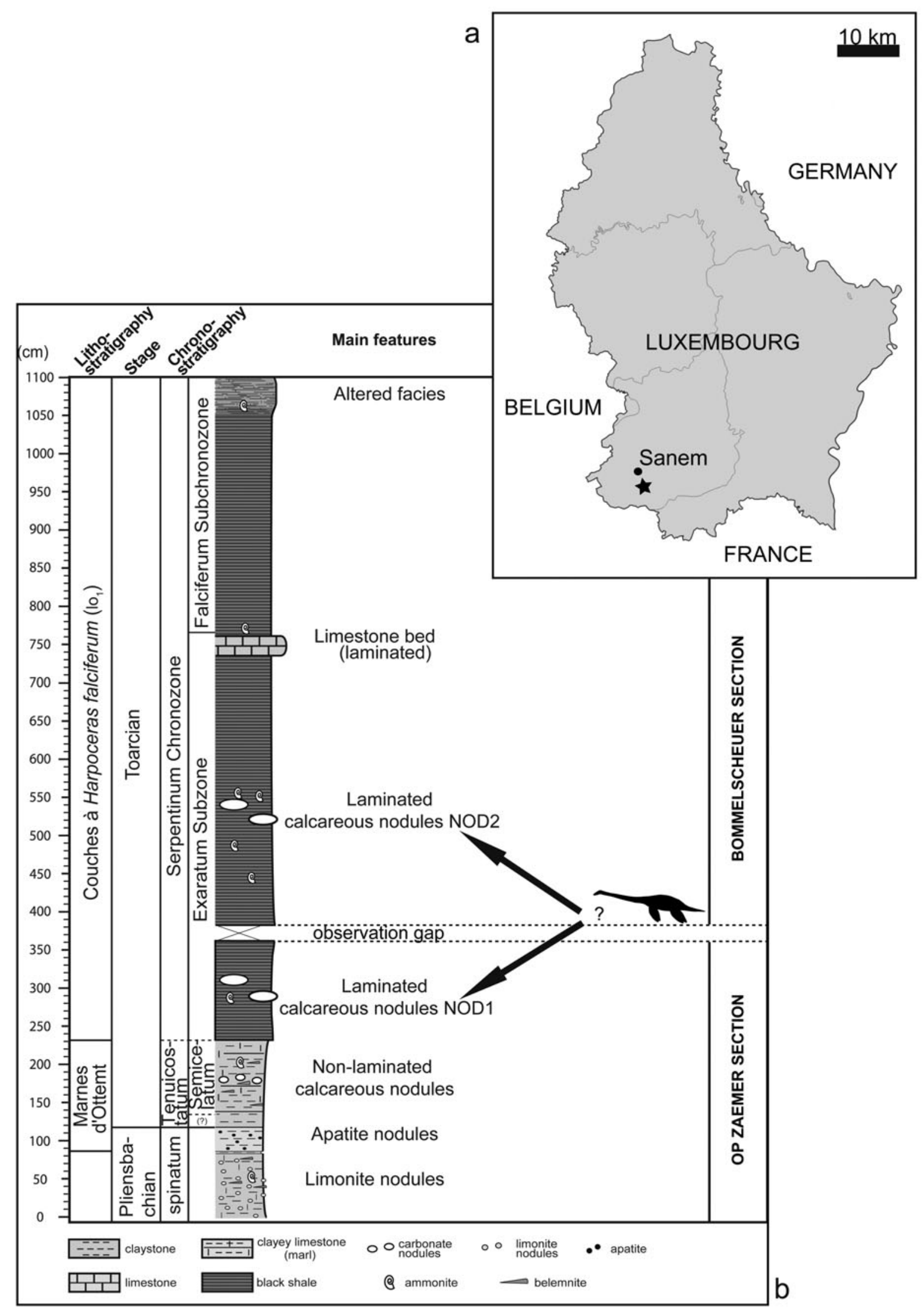

Figure 1. (a) Map showing the locality where the holotype of Microcleidus melusinae (MNHNL TV434) was collected. (b) Simplified Lower Jurassic succession of Luxembourg based on outcrops and drill cores (modified from Hermoso et al. 2014), with the possible stratigraphic position of Microcleidus melusinae (MNHNL TV434), as indicated by arrows. 


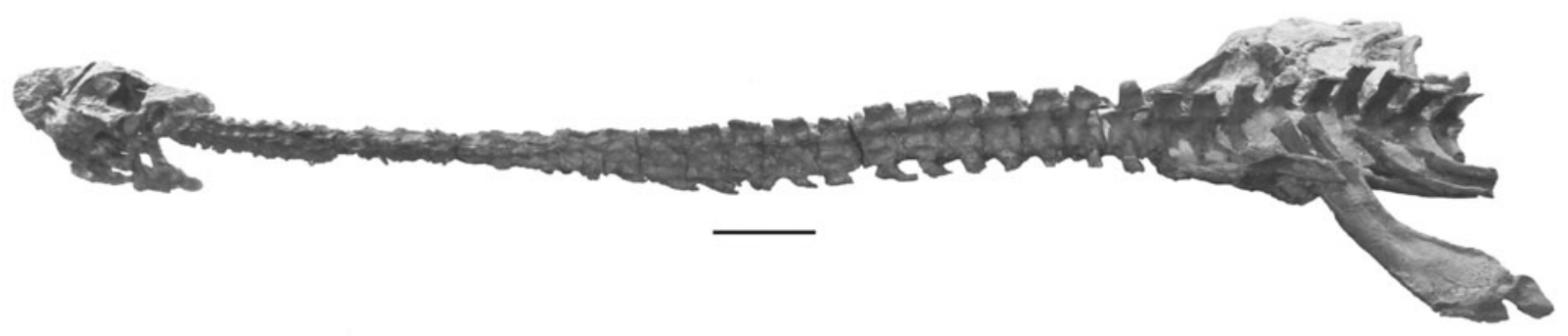

Figure 2. Mounted holotype of Microcleidus melusinae (MNHNL TV434) in left oblique view. Scale bar equals $10 \mathrm{~cm}$.

\section{Systematic palaeontology}

\author{
SAUROPTERYGIA Owen, 1860 \\ PLESIOSAURIA de Blainville, 1835 \\ Plesiosauroidea Welles, 1943 \\ MicrocleididAe Benson, Evans \& Druckenmiller, \\ 2012 \\ Genus Microcleidus Watson, 1909
}

Type species. Microcleidus homalospondylus (Owen, 1865-1881), from the upper Lias of Whitby, Yorkshire (see Brown, Vincent \& Bardet, 2013).

\section{Microcleidus melusinae sp. nov.}

Derivation of name. The specific name is derived from the French name 'Melusine', the name of a mythical woman who is a serpent or fish from the waist down. Melusine is part of European folklore and is said to have been married to Count Siegfried, considered the first count of Luxembourg.

Type specimen. MNHNL TV434, a skull with a partial postcranial skeleton (Figs 2-9).

Diagnosis. Small-bodied plesiosauroid with the following unique combination of characters: unconstricted snout (between the premaxilla and maxilla), weak participation of the prefrontal to the naris margin, frontal excluded from the orbital margin, posteriorly elongated jugal that terminates anteriorly around the posterior orbital margin and is excluded from the orbital margin, postorbital posterolateral process long, parietal foramen situated just posterior to the parietal frontal suture, absence of an anterior interpterygoid vacuity, pterygoids do not meet each other posterior to the posterior interpterygoid vacuity, a keeled parabasisphenoid, a smooth enamel on the labial surface of the tooth, 30 postaxial cervical vertebrae, short anterior cervical centra, absence of a longitudinal ridge on anterior cervical vertebrae, and an anteroposterior constriction at the base of the dorsal neural spines. Microcleidus melusinae differs from the other species of Microcleidus as it possesses a slightly longer anterior extension of the jugal than that reported for $M$. brachypterygius, a shorter participation of the prefrontal to the naris margin than that observed in $M$. brachypterygius, a pineal foramen contra that reported in M. tournemirensis, a rim of the pineal foramen that is raised dorsally from the surrounding surfaces contra that observed in M. brachypterygius, a frontal excluded from the orbital margin contra that reported for M. tournemirensis and M. homalospondylus, a smooth enamel on the labial surface of the tooth contra M. brachypterygius and M. tournemirensis, and 30 postaxial cervical vertebrae contra that observed in $M$. homalospondylus and M. tournemirensis.

Geographical and stratigraphical occurrence. From the surroundings of Sanem, Esch-sur-Alzette canton in the southwest of Luxembourg. 'Couches à Harpoceras falciferum', Lower Toarcian, Serpentinum Chronozone, Exaratum Subchronozone.

\section{Description}

\section{4.a. Ontogenetic stage}

The cervical vertebrae for which the neural arches and ribs are observable show a closed suture with the centra, whereas the limb bones are well developed and present well-defined articular facets, indicating that the specimen is an osteologically mature specimen sensu Araújo et al. (2015) or an 'adult' individual sensu Brown (1981).

\section{4.b. General preservation}

The skull is slightly crushed and many cracks run through the bones both on the dorsal and ventral surfaces. Slight dorsoventral crushing has decreased the height of the cranium, and disarticulated some bones, especially around the orbit, the braincase and the ventral margins of the temporal fenestrae. The left jugal has been rotated lateroventrally and the squamosal arch, broken into several pieces, has been rotated anteroventrally. However, the squamosal would have originally been more vertical. The posterior part of the skeleton is not preserved; neither is the right forelimb (Fig. 2). The pectoral girdle is only partially observable.

\section{4.c. Skull}

The skull is relatively narrow and is $c .157 \mathrm{~mm}$ long from the tip of the snout to the posterior border of the squamosal arch (Fig. 3). The orbits are situated approximately at the cranial midlength, although the preorbital skull length (slightly less than $60 \mathrm{~mm}$ ) is 


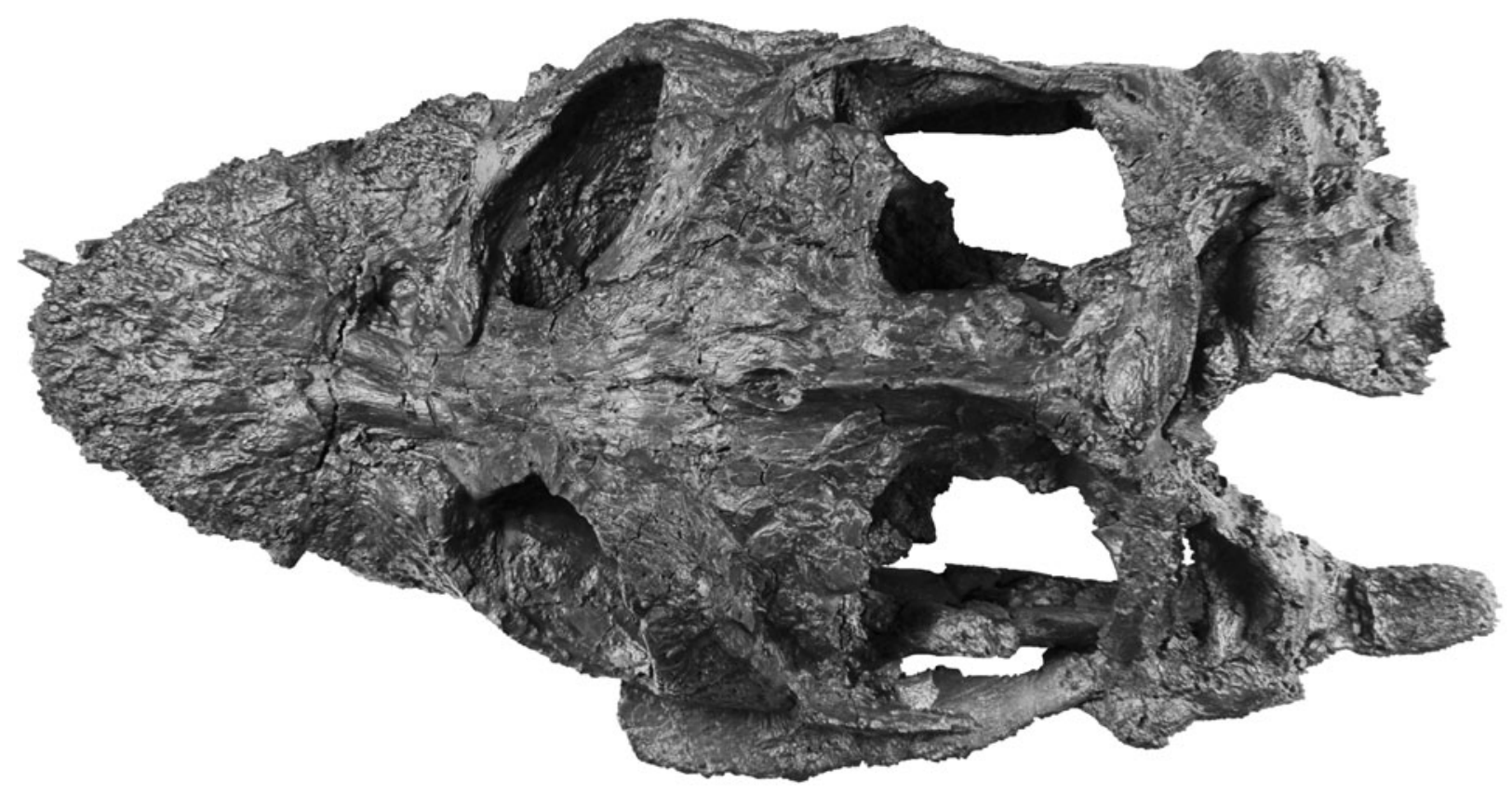

a

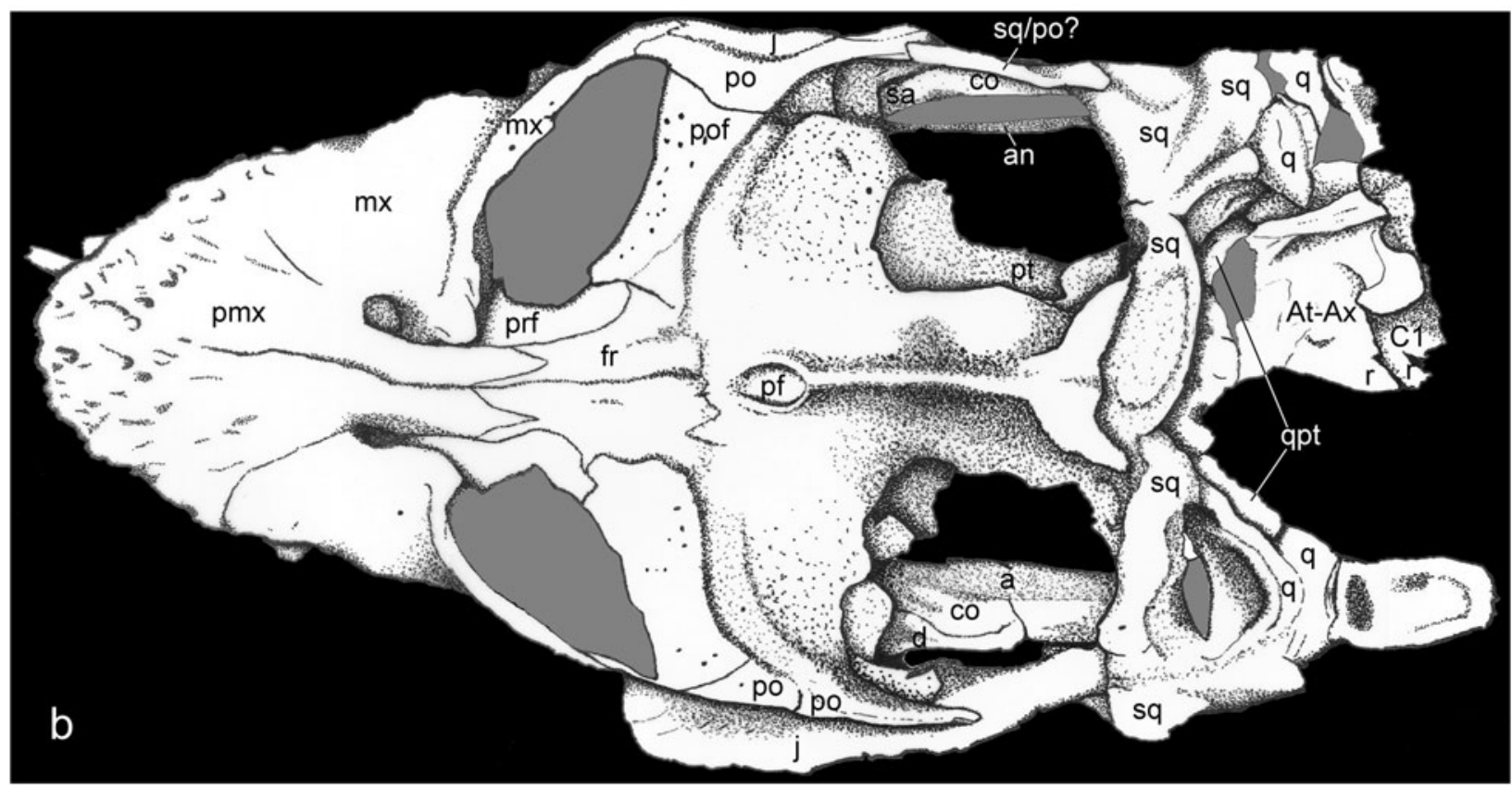

Figure 3. Skull of the holotype of Microcleidus melusinae (MNHNL TV434) in (a) dorsal view, and (b) line drawing; grey tone indicates matrix. Abbreviations: a - angular; At-Ax - atlas-axis complex; $\mathrm{Cl}$ - first postaxial cervical vertebra; co - coronoid; $\mathrm{d}-$ dentary; fr - frontal; jug - jugal; pmx - premaxilla; mx - maxilla; pf - pineal foramen; po - postorbital; pof - postfrontal; prf prefrontal; pt - pterygoid; q - quadrate; qpt - quadrate ramus of pterygoid; $r$ - rib; sa - surangular; sq - squamosal. Scale bar equals $10 \mathrm{~cm}$.

slightly less than the postorbital skull length (slightly less than $70 \mathrm{~mm}$ ). As in other plesiosaurians (Storrs, 1991: character 35), the external nares are retracted, and located only a short distance anterior to the orbits. The orbits are ovoid in shape and dorsolaterally orientated. The forwardly facing orbit suggests a certain degree of stereoscopic vision. The temporal fenestrae are large and almost quadrangular in shape.

The premaxillae (Fig. 3) form the anterior part of the snout and produce posteromedial processes that extend posterodorsally between the orbits. The external surface of the premaxillary rostrum bears numerous foramina arranged in shallow, anteroventrally orientated sulci similar to those in the holotype of Microcleidus brachypterygius (Maisch \& Rücklin, 2000; Großmann, 2007). The inter-premaxilla suture is closed anteriorly and tightly jointed posteriorly. The left premaxillamaxilla suture originates posterior to the fifth premaxillary alveolus and extends posterodorsally to contact the anterodorsal border of the external naris (Fig. 3). 
Bone surface damage and fragmentation and possible fusion between the two bones make it difficult to determine the morphology of the right premaxillamaxilla suture. Microcleidus melusinae lacks a transverse 'rostral' constriction between the premaxilla and maxilla, unlike many large-headed plesiosaurians (e.g. Taylor, 1992; O'Keefe, 2001; Druckenmiller \& Russell, 2008; Smith \& Dyke, 2008), but similar to many small-headed taxa (e.g. Microcleidus homalospondylus). Posterior to the external nares, the premaxillary facial processes articulate with the frontals at the level of and terminate adjacent to the orbit midlength. Each premaxillary facial process forms a triangular projection separating each frontal anterior extension into two tapering shafts. A similar condition is reported for the holotype of $M$. brachypterygius (Maisch \& Rücklin, 2000) and the Triassic sauropterygians Augustasaurus and Pistosaurus (Rieppel, Sander \& Storrs, 2002). The posterior rami dorsal surfaces do not show any nutrient foramina. There is no premaxillary dorsomedian foramen.

The dorsolateral surface of the maxilla bears numerous small nutrient foramina (Fig. 3). The maxillae form the anterolateral and lateral margins of the external nares, and the anterior and anteroventral margins of the orbits. The ascending processes of the maxillae border the anteromedial margins of the orbits and seem to overlap the prefrontals posteriorly. The maxillae extend beneath the orbits to contact the jugals lateroventrally and the postorbitals laterodorsally (Figs 3, 4).

The prefrontals line the orbits anterodorsally. Their sutures with the frontals are clearly visible extending round the orbital borders (Fig. 3). On the left side, the anterior portion of the prefrontal contacts the external naris (considered here as a small, almost point-like, participation to the margin of the naris contra that observed in $M$. brachypterygius) and meets the maxilla in a long suture. On the right side, the extension anteriorly is not clear owing to slight crushing and distortion in this region. Posteriorly, the prefrontals contact the postfrontals, excluding the frontals from the orbital margin as in $M$. brachypterygius but not $M$. homalospondylus and M. tournemirensis.

The frontals form the central part of the skull table in the interorbital region between the parietals posteriorly and the premaxillae anteriorly. The frontals are overlain anteriorly by the facial processes of the premaxillae and border the prefrontals anterolaterally. The frontals are united along the midline as in all Jurassic plesiosauroids (Brown, Vincent \& Bardet, 2013). The widest part of the frontals is behind the prefrontals where they contact the postfrontals laterally. They extend posteriorly to meet the parietals at the margin of the bulging bone structure surrounding the pineal foramen. Although the bones in this area are damaged, it seems that the frontals do not contact the pineal foramen, but meet the parietals in an interdigitating suture just anterior to the pineal foramen as in $M$. brachypterygius (Großmann, 2007).
The paired parietals form a median dorsal roof over the endocranial cavity and meet in the dorsal midline to form a thin sagittal crest between the temporal fossae (Figs 3, 4). As in M. brachypterygius, the crest starts immediately behind the pineal foramen. Anteriorly, the parietals suture with the frontals and make contact with the postfrontals and possibly with the postorbitals. The parietals suture posteriorly with the squamosals. The pineal foramen (10 $\mathrm{mm}$ long) is an anteroposteriorly elongate wide oval in dorsal view, as in Anningasaura. It is located anteriorly on the parietals and its rim is raised dorsally from the surrounding surfaces (Fig. 3), contra that observed in $M$. brachypterygius.

The large postfrontals form the entire posterior margins of the orbits as in $M$. brachypterygius and $M$. homalospondylus (Figs 3, 4). The lateral processes of the postfrontals form the anterodorsal portions of the postorbital bar. They are marked by numerous small foramina as in M. brachypterygius.

The postorbitals are relatively large triradiate elements as in Plesiosaurus (Storrs, 1997), Seeleyosaurus (SMNS 12039; Großmann, 2007, text-fig. 3) and $M$. homalospondylus (Brown, Vincent \& Bardet, 2013). The anterior (orbital) process of each postorbital meets the maxilla, forming part of the posterolateral border of the orbit. Ventrally, the postorbitals are overlain by the jugals (Figs 3,4). They thus exclude the jugals from contact with the orbits. The long, posteroventral processes of the postorbitals extend posteriorly along the dorsolateral surfaces of the jugals, extending for half of the length of the temporal fenestra on the left side (Fig. 3) contra that observed in $M$. homalospondylus. However, they have probably been damaged on both sides and the left side is incompletely preserved, so that the real extension of the bones is unknown. On the right side, the contact between the postorbital and the squamosal is observable via a thin piece of bone corresponding to either the postorbital or the squamosal (Fig. 4a).

The jugal is well preserved on the left side and is a plate-like, transversely thin bone that forms the posteroventral margin of the skull roof (Figs 3, 4). It does not contact the orbit margin as in Microcleidus tournemirensis (Bardet, Godefroit \& Sciau, 1999), M. homalospondylus and M. brachypterygius. It overlaps the postorbital dorsally, the maxilla anteriorly and ventrally, and meets the squamosal posteriorly. It extends anteriorly from the posterior orbital margin for one-third of the orbital length. Its anterior extension is thus more reduced than that observed in $M$. homalospondylus but slightly more developed than that reported in $M$. brachypterygius. Numerous foramina of varying sizes are present on the lateral surface of the left jugal.

Both squamosals are crushed and meet in a midline suture (Figs 3, 4), but the morphology of the squamosal symphysis is not clear. The paired squamosals form the dorsolateral rim of the suspensorium, and most of the temporal bar. The dorsal rami of the squamosals form the posterior margin 

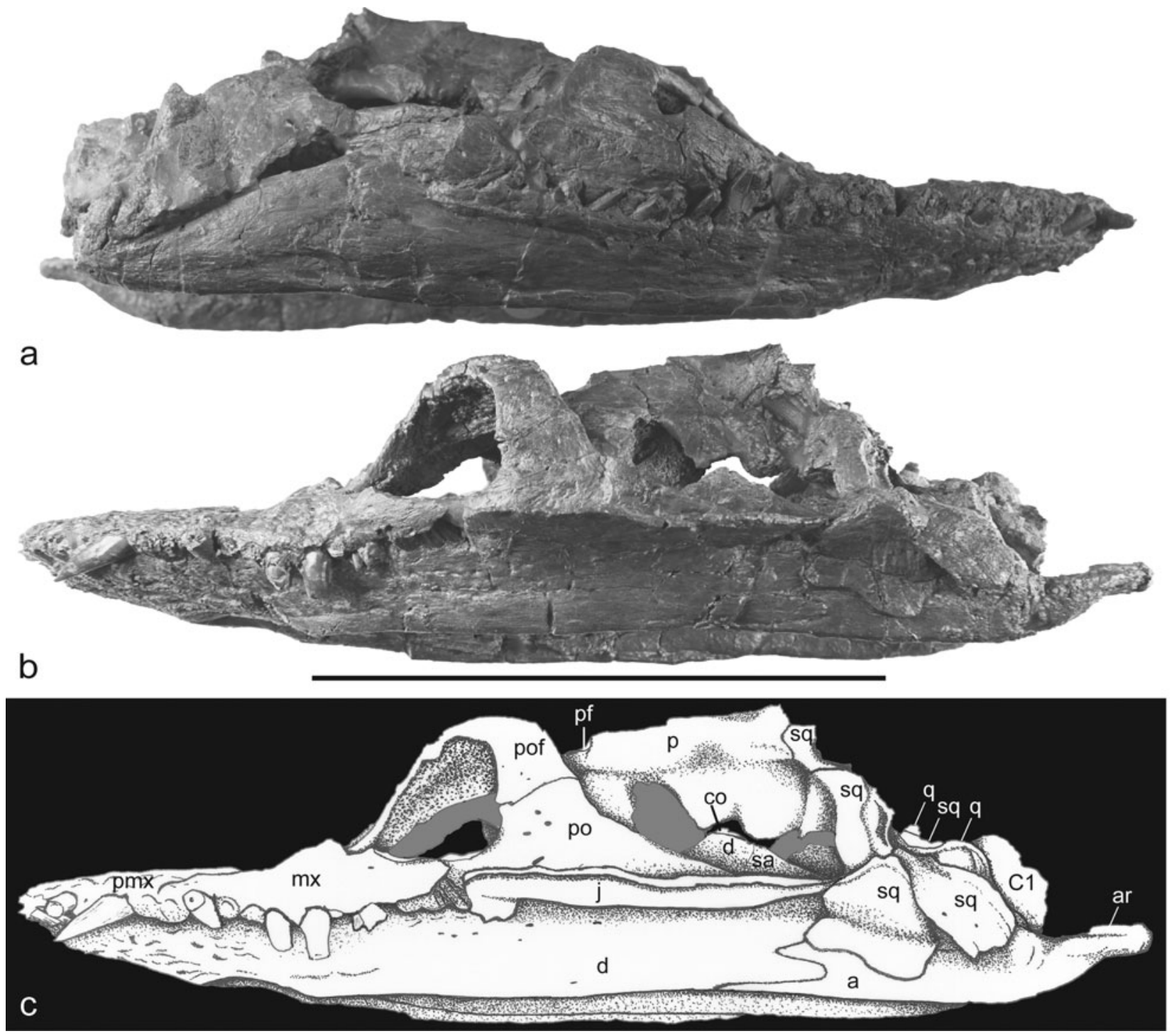

Figure 4. Skull of the holotype of Microcleidus melusinae (MNHNL TV434), photographs in (a) right lateral view, (b) left lateral view, and (c) line drawing; grey tone indicates matrix. Abbreviations: a - angular; ar - articular; $\mathrm{C} 1$ - first postaxial cervical vertebra; co coronoid; $\mathrm{d}$ - dentary; $\mathrm{j}$ - jugal; $\mathrm{mx}$ - maxilla; $\mathrm{p}$ - parietal; $\mathrm{pf}$ - pineal foramen; pmx - premaxilla; po - postorbital; pof - postfrontal; $\mathrm{q}$ - quadrate; sa - surangular; sq - squamosal. Scale bar equals $10 \mathrm{~cm}$.

of the temporal fenestra. The anterior ramus of the right squamosal forms the temporal bar, which arches dorsally and contacts the jugal and the postorbital anteriorly. The suspensorium appears inclined anterodorsally.

Both quadrates are partially preserved but are crushed to some extent, making the estimation of their original shape, extent and contacts difficult (Figs 3, 4). Unfortunately, many of the sutural contacts between the squamosals, quadrates and pterygoids are impossible to locate. The quadrates seem to be stout bones mediolaterally convex in posterior view. Ventrally, the left quadrate condyle is broken just above the mandibular condyle. There is no indication of a quadrate foramen. The marked ridge present on the posterior surface of the quadrate of M. brachypterygius (Maisch \& Rücklin, 2000) is not present.

\section{4.d. Palate and braincase}

Much of the palate lateral to the pterygoid and posterior to the vomer is disarticulated and broken, so identification of the palatal bones, including both palatines, is difficult (Fig. 5). Most of the braincase is not preserved.

The palatines seem to be large, elongated elements (Fig. 5). Their contacts with the maxillae are not visible. Medially, they overlie the lateral parts of the anterior processes of the pterygoids. With the internal nares being hidden by the mandible preserved in occlusion in palatal view and some residual sedimentary matrix and resin, the presence of a contact between the palatines and the internal nares cannot be attested.

The ectopterygoids appear as poorly preserved, small elements on both sides (Fig. 5). Their anterior extensions are unknown on both sides. Their ventral surfaces are almost flat. 

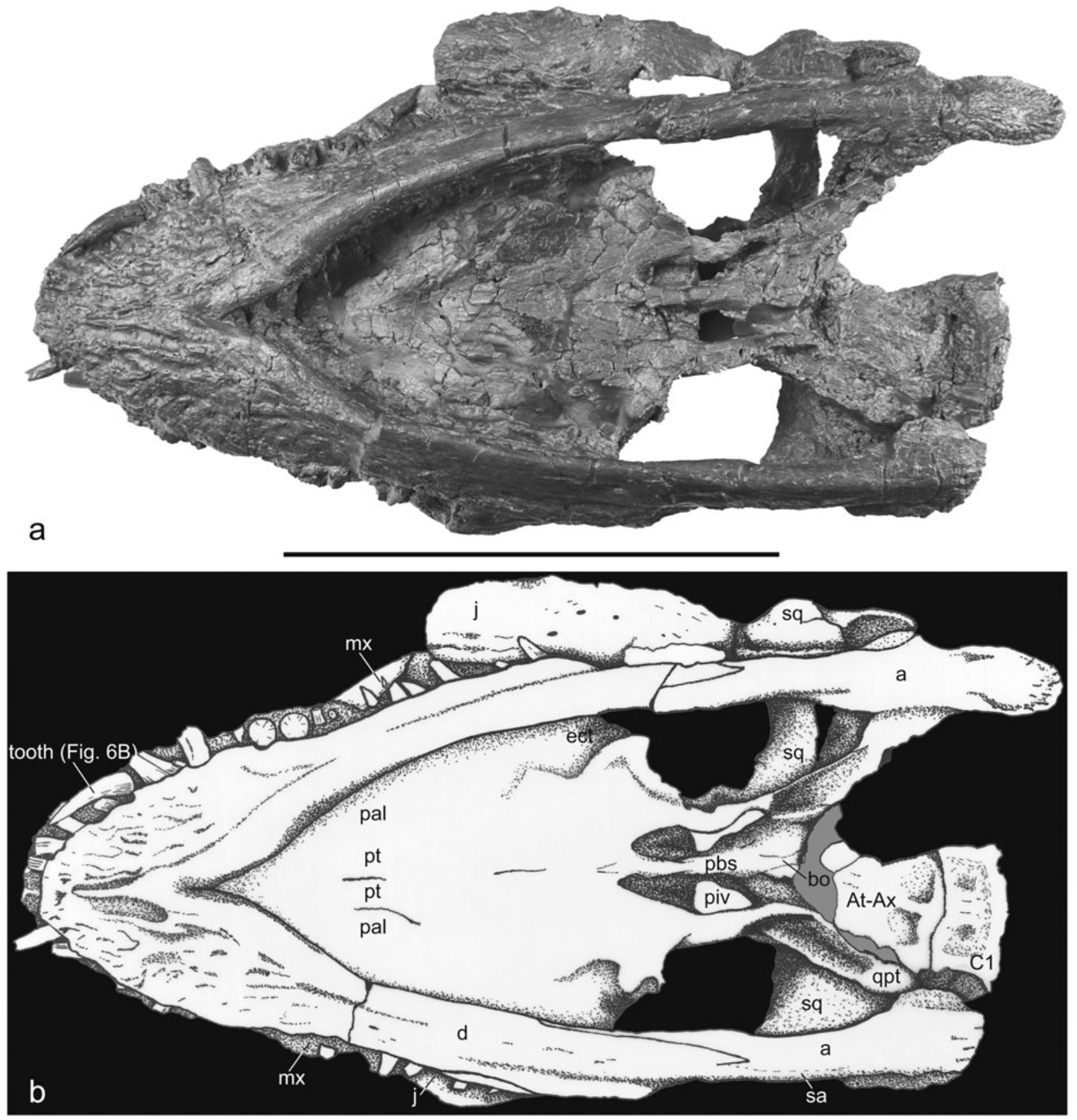

Figure 5. Skull of the holotype of Microcleidus melusinae (MNHNL TV434) in (a) ventral view, and (b) line drawing; grey tone indicates matrix. Abbreviations: a - angular; At-Ax - atlas-axis complex; C1 - first postaxial cervical vertebra; bo - basioccipital; ect - ectopterygoid; pbs - parabasisphenoid; piv - posterior interpterygoid vacuity; ect - ectopterygoid; j - jugal; $\mathrm{mx}$ - maxilla; pal palatine; pt - pterygoid; qpt - quadrate ramus of pterygoid; sa - surangular; sq - squamosal. Scale bar equals $10 \mathrm{~cm}$.

The paired pterygoids form anteriorly tapering processes that make up the central portion of the palate (Fig. 5). There is no anterior interpterygoid vacuity and the pterygoids meet along the midline. They are overlain laterally by the palatines. Posteriorly, the pterygoids develop dorsally into vertically orientated flanges, curved in shape, which run posteriorly, forming the medial boundaries of the subtemporal fenestrae and becoming the quadrate rami. The presence of a prominent ventrolateral flange is reported in pliosaurids (e.g. Andrews, 1913; Druckenmiller \& Russell, 2008; Ketchum \& Benson, 2011) and microcleidids
(Benson, Evans \& Druckenmiller, 2012; Brown, Vincent \& Bardet, 2013). Posterior to the posterior interpterygoid vacuity, the pterygoids make no posteromedial contact with each other on the midline (Figs 5, $6 a)$, but are separated by a very thin ventral exposure of the basioccipital (Fig. 5).

The parabasisphenoid forms a ventral midline keel that bisects the posterior interpterygoid vacuity. A crested parabasisphenoid is usually found in pliosaurids (e.g. Taylor \& Cruickshank, 1993b), leptocleidids (e.g. Druckenmiller \& Russell, 2008), polycotylids (Druckenmiller, 2002) and elasmosaurids 


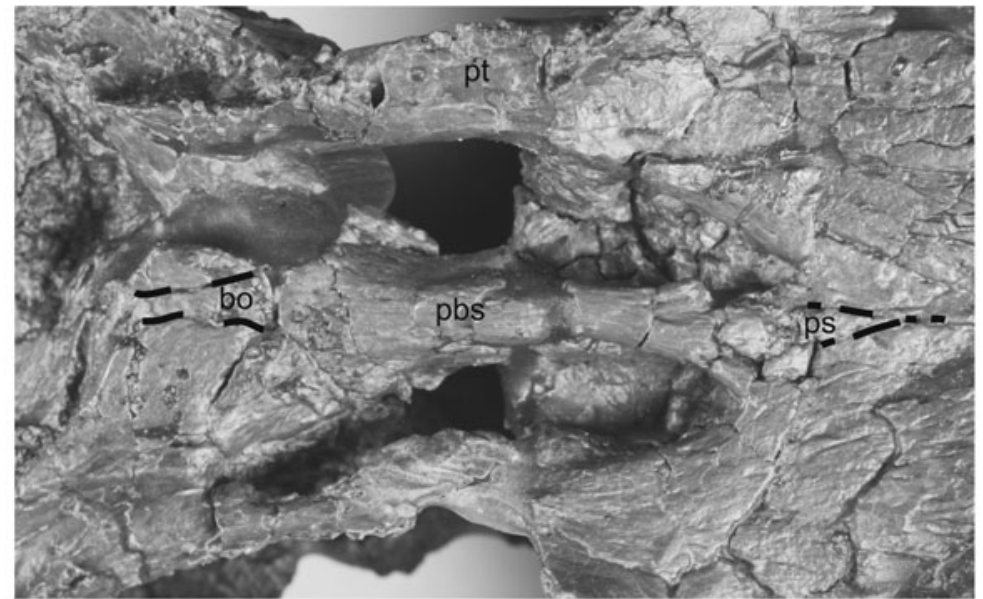

a

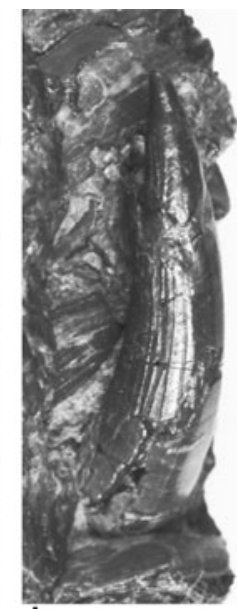

b
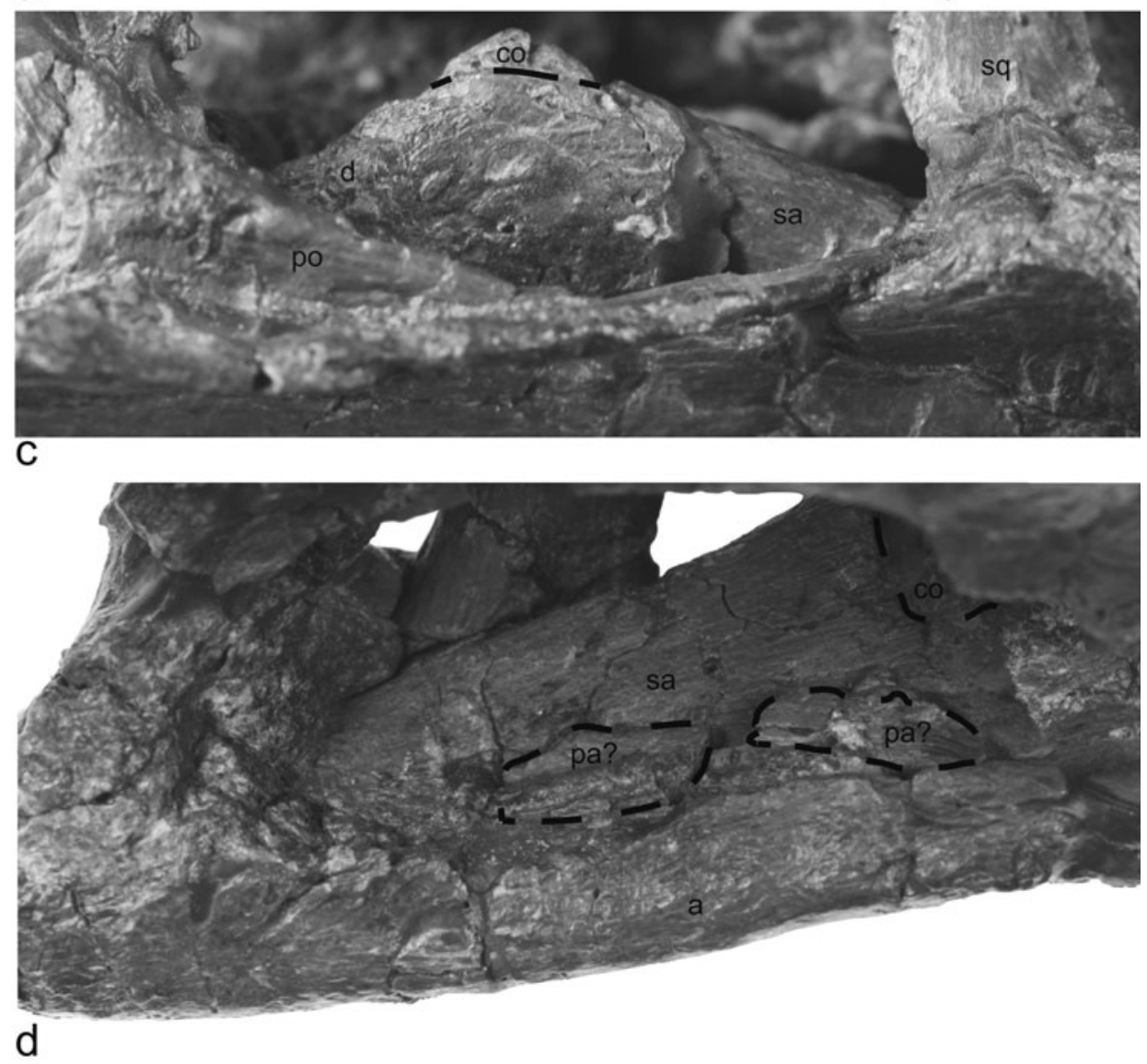

Figure 6. Close-ups of the skull of the holotype of Microcleidus melusinae (MNHNL TV434). Photographs of (a) the posterior portion of skull in ventral view, dotted lines indicate possible suture between the parasphenoid and pterygoids, and between the basioccipital and the parabasisphenoid; (b) premaxillary tooth; (c) posterior portion of the right mandible in lateral view showing the coronoid eminence; (d) posterior portion of the left mandible in medial view. Abbreviations: a - angular; bo - basioccipital; co - coronoid; $d$ dentary; pa - prearticular; pbs - parabasisphenoid; po - postorbital; ps - parasphenoid; pt - pterygoid; sa - surangular; sq - squamosal.

(Eromangasaurus, Tuarangisaurus, Libonectes and Callawayasaurus; Brown, Vincent \& Bardet, 2013), whereas the ventral surface of this bone is flat in the Jurassic plesiosauroids Lusonectes (Smith, Araújo \& Mateus, 2012), Plesiosaurus and Muraenosaurus, except for M. tournemirensis and M. homalospondylus. The location of the suture between the parasphenoid cultriform process and the pterygoids anteriorly cannot be determined with certainty, but if correctly recognized the parasphenoid seems to have a short exposure in palatal aspect (Figs 5, 6a). Posteriorly, parasphenoid-basisphenoid sutures are not visible indicating a possible fusion between the two bones.

The anterior part of the basioccipital seems to be largely covered by the pterygoids in ventral view, except for a very thin strip of bone. It results in the separation of the pterygoids posterior to the posterior interpterygoid vacuity by a narrow ventral exposure of 
the basioccipital. This condition is also observed in Triassic pistosaurians (Sues, 1987; Rieppel, Sander \& Storrs, 2002; Cheng et al. 2006) and many early plesiosaurians, including Plesiosaurus (Storrs, 1997), M. brachypterygius (S. Sachs, pers. com. 2016), cryptoclidids (Andrews, 1910) and Thalassiodracon (Benson et al. 2011), in which the pterygoids do not contact each other posteriorly. However, it is unlike the situation in M. homalospondylus and derived plesiosauroids (O'Keefe, 2001), in which the pterygoids meet each other posteriorly in a medial suture, covering the ventral surface of the basicranium. The occipital condyle is not observable, possibly obscured by matrix and the atlas.

\section{4.e. Mandible}

The mandible is almost complete, except for the missing posterior end of the right mandibular ramus, and is preserved in life position (Figs 4, 5). It measures $c$. $21 \mathrm{~cm}$. The dorsomedial parts of the jaws are not visible because the jaws are occluded. There is no trough on the lateral side of the mandible.

The dentaries cover the anterior two-thirds of the mandible (Fig. 5). On the lateral surface of the dentaries, at the level of the coronoid eminences, the dentaries interdigitate with the surangulars dorsally and the angulars ventrally (Fig. 4). Anteriorly, the external surface is ornamented with neurovascular foramina. The mandibular symphysis is $3.4 \mathrm{~cm}$ long on the anteroventral surface and comprises probably only the dentaries. There is no lateral expansion at the symphysis, although there is slight expansion just posterior to it. The four mesialmost dentary alveoli are incorporated into the symphysis, as in Plesiosaurus, Microcleidus and Thalassiodracon (Storrs \& Taylor, 1996). The symphysis is long relative to the overall length of the skull (16\%), as in M. homalospondylus and Plesiosaurus (Brown, Vincent \& Bardet, 2013).

The coronoids are preserved, sandwiched between the dentaries, the angulars and the surangulars at their highest points (Fig. 6d). Their top edges thus form the rounded summits of the coronoid eminences, which are distinctly high and pointed (Fig. 6c).

The surangulars are triangular bones that occupy a large portion of the posterior parts of the mandible rami (Fig. 4a). Medially, the surangulars are well visible between the coronoids and the prearticulars. The left surangular is not clearly observable in lateral view and its lateral suture with the angular is thus not visible owing to the poor state of preservation of the bone surface and because it is partially covered by some crushed elements. On the right side, the surangular descends to the glenoid fossa posterior to the coronoid eminence.

The angulars are long and narrow bones forming the posteroventral portions of the mandible rami (Figs 4, $5,6 \mathrm{c}, \mathrm{d})$. At the level of the coronoid eminences, the angulars contact the dentaries and the surangulars in lateral view. The medial surfaces of the angulars are underlined by the fragmentary prearticulars. Posterolaterally, the angulars underlap the surangulars and articulars.

The articulars are robust bones exposed mainly dorsally and forming the glenoid fossa and most of the retroarticular processes. The posterior surface of the retroarticular process is smooth and slightly concave. The glenoid cavities are not observable.

\section{4.f. Teeth}

Numerous teeth are preserved in situ (Fig. 4). They are slender and recurved, with a subcircular cross-section (Fig. 6b). They taper towards a pointed apex. The enamel is ornamented with coarse apicobasal ridges on the lingual, mesial and distal surfaces, but is smooth on the labial surface (Fig. 6b). As far as it can be estimated from the broken teeth and alveoli, the dentition appears rather regular in size, only the anterior- and posteriormost alveoli being smaller. The largest teeth occur around the premaxilla-maxilla suture.

There are five premaxillary teeth, and the mandibular symphysis accommodates four alveoli. The total counts for the maxillary and dentary teeth are not available because the jaws are occluded. At least 18 alveoli are present in the right dentary (although more should have been present posteriorly).

\section{4.g. Axial skeleton}

Microcleidus melusinae preserves the atlas-axis complex articulated with the skull, the complete series of cervical vertebrae (30 additional centra and most of their corresponding neural arches and ribs), two pectoral vertebrae, two pectoral or dorsal vertebrae that cannot be assigned to either owing to lack of information and five dorsal vertebrae with their corresponding ribs.

The atlas and axis are preserved still embedded in the matrix and are observable in ventral view. They seem to be fused, forming a single unit. The ventral surface is convex with a faint median keel that extends along the posterior half of the atlas-axis complex. The keel tapers posteriorly, merging with rugosities which ring the posterior face of the axis centrum. The length of the atlas-axis complex is $20 \mathrm{~mm}$.

Thirty postaxial cervical vertebrae are preserved as five articulated and unbroken series (Fig. 7). The anterior cervical centra are wide and shorter anteroposteriorly than high $(\mathrm{W}>\mathrm{H}>\mathrm{L})$; the posterior cervical centra are approximately wider than they are high dorsoventrally and long anteroposteriorly $(\mathrm{W}>$ $\mathrm{L}>\mathrm{H})$. This condition is similar to that observed in Stratesaurus (Benson, Evans \& Taylor, 2015), but differs from that observed in $M$. brachypterygius (Huene, 1923; Großmann, 2007: character 28), M. tournemirensis (Bardet, Godefroit \& Sciau, 1999) and M. homalospondylus (Benson, Evans \& Druckenmiller, 2012: character 116). The articular surfaces are 


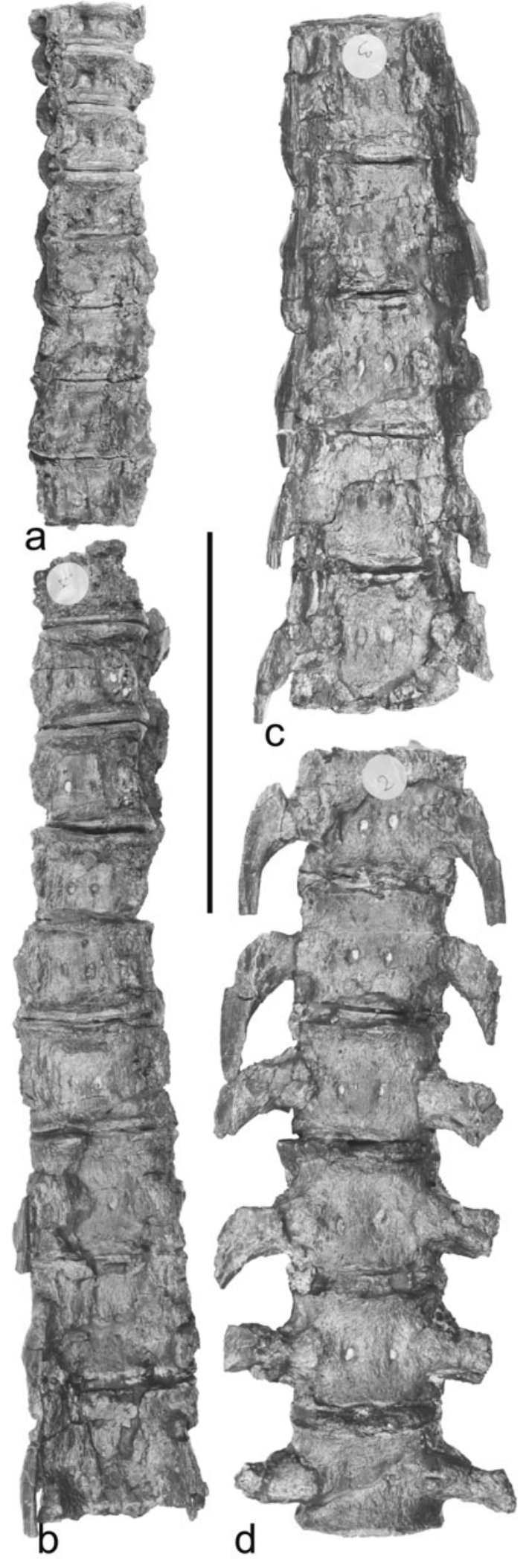

Figure 7. Cervical vertebrae of the holotype of Microcleidus melusinae (MNHNL TV434) in ventral view: (a) C2-C9; (b) C10-C18; (c) C19-C23 and (d) C24-C29. Scale bar equals $10 \mathrm{~cm}$ gently concave. The anterior surface of each centrum does not extend ventrally as a low, midline 'lip'. The ventral surface of each centrum bears paired subcentral foramina, either side of a very low ventral longitudinal ridge and set in squared depressions in the anteriormost cervical vertebrae (C1-C4) (Figs 7a, 8a). The lateral surfaces of the cervical centra do not bear any longitudinal ridge (Fig. 8b), except the cervical C24 and $\mathrm{C} 25$, which bear a very poorly developed ridge (Fig. 8f); M. melusinae thus differs from M. brachypterygius (specimen MH Nr. 8 referred to as $M$. brachypterygius by Großmann, 2007).

The cervical rib facets are located ventrolaterally (Figs 7a, 8a) and are anteroposteriorly long, occupying most of the anteroposterior length of the centrum in anterior cervical centra $(\mathrm{C} 1-\mathrm{C} 16 / \mathrm{C} 17)$. Anterior cervical centra bear a single rib facet $(\mathrm{C} 1-\mathrm{C} 7 / \mathrm{C} 9)$, which is divided into dorsal and ventral facets by a longitudinal thin groove from the cervical C11 (Fig. 8c), as is common in early plesiosaurians (Benson, Evans \& Taylor, 2015). The cervical rib facets of $M$. melusinae are only weakly divided (including in the posteriormost cervicals) and the dorsal facet is slightly smaller than the ventral facet. Numerous cervical ribs are preserved. The majority are articulated with vertebrae (Fig. 8d, e) and are firmly sutured with the centra. However, some were likely broken during burial. The cervical rib shafts of $M$. melusinae are transversely narrow with a convex dorsolateral surface and a slightly concave ventromedial surface. The rib bears distinct anterior and (larger) posterior processes (Fig. 7). The pre- or postzygapophyses are small, not medially united to each other, and their combined widths are narrower than the centrum. The prezygapophyseal facets face dorsomedially, and the postzygapophyseal facets face ventrolaterally. None of the cervical neural spines of M. melusinae are complete except those of the cervical C2 and C3 (Fig. 8b). Their outlines in lateral view taper towards a posterodorsally recurved apex in the anteriormost cervical vertebrae. The apex is not preserved in other cervical vertebrae. The outlines of the ventral part of all the spines in lateral view are subrectangular and slightly inclined anteriorly, forming two parallel edges (Fig. 8e).

A total of nine post-cervical vertebrae are preserved. The two first vertebrae following the cervicals are pectoral vertebrae (Fig. 8g). The vertebrae situated immediately posterior to these two pectorals are hardly determinable, most of the specimen's trunk being still embedded in the matrix and only dorsally prepared. The exact number of pectorals (between two and four) remains thus unclear as the following vertebrae could correspond to either pectoral or dorsal vertebrae. Pectoral vertebrae are characterized by a rib facet formed from both the centrum and neural arch. The undivided rib facet is higher dorsoventrally than wide anteroposteriorly. The zygapophyses are small and have a similar configuration to those of the cervical vertebrae. The neural spines are broken. 

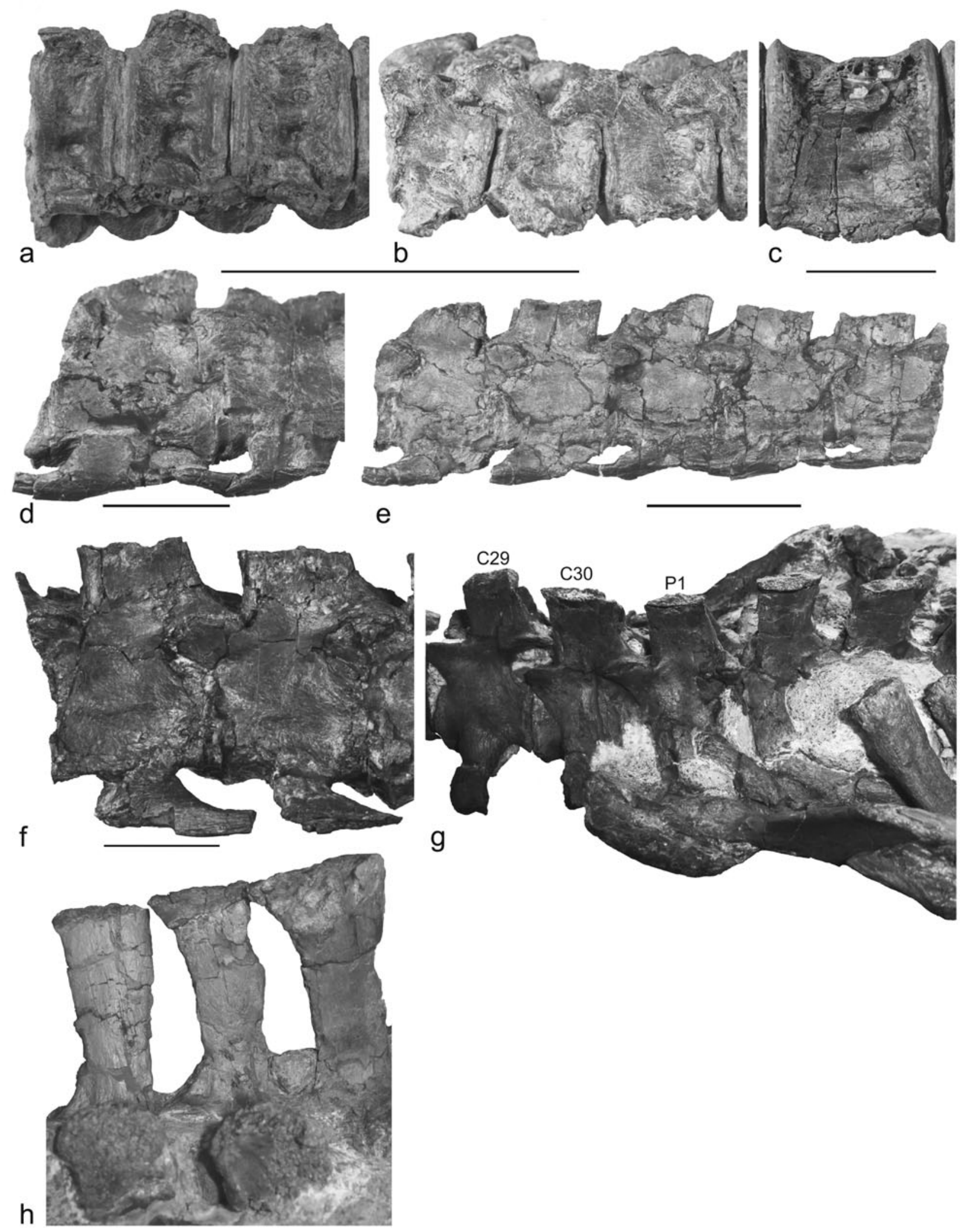

Figure 8. Vertebrae of the holotype of Microcleidus melusinae (MNHNL TV434): (a, b) C2-C4 in (a) ventral, and (b) left lateral view; (c) C11 in ventral view; (d) C17-C18 in right lateral view; (e) C19-C23 in right lateral view; (f) C24-C25 in left lateral view; (g) posteriormost cervical vertebrae C29 and C30 and pectoral vertebrae in oblique (laterodorsal) view; (h) dorsal neural spines in right lateral view. Abbreviations: $\mathrm{C}$ - postaxial cervical vertebra with number; $\mathrm{P}$ - pectoral vertebra with number. Scale bars equals $5 \mathrm{~cm}$ $(\mathrm{a}, \mathrm{b}, \mathrm{e})$ and $2 \mathrm{~cm}(\mathrm{c})$ and $2.5 \mathrm{~cm}(\mathrm{~d}, \mathrm{f})$. 


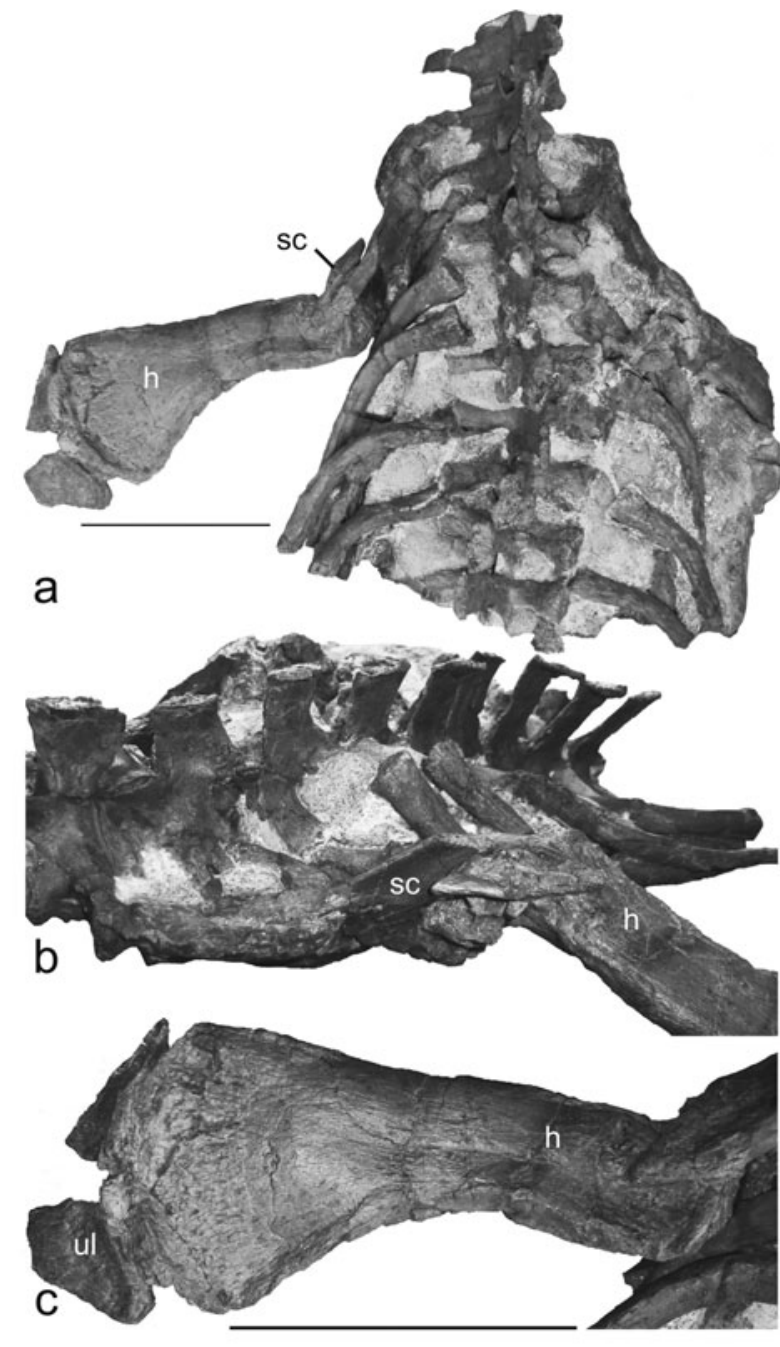

Figure 9. Axial and appendicular skeleton of Microcleidus melusinae (MNHNL TV434): (a, b) thoracic skeleton segment in (a) dorsal and (b) oblique view; (c) left humerus in dorsal view. Abbreviations: $\mathrm{h}$ - humerus; sc - scapula; $\mathrm{ul}$ - ulna. Scale bar equals $10 \mathrm{~cm}$ (a).

At least the last five preserved vertebrae are dorsals. The dorsal centra are still almost entirely embedded in the matrix but the neural arches, spines and transverse processes are free from the matrix. The neural arches have stout transverse processes with convex spherical ends for attachment of ribs that are oriented upwards and outwards. The neural spines are tall, thin and quadrangular in lateral view, laterally compressed and long anteroposteriorly. The bases of the neural spines present an anteroposterior constriction (Fig. 8h). Several partial dorsal ribs are preserved still embedded in the matrix. They have long curved shafts (Fig. 9).

\section{4.h. Girdle and paddle}

The pectoral girdle of the specimen is partially preserved and almost entirely embedded in the matrix (Fig. 9a). The left scapula is partially observable and an indeterminate element preserved on the right side could represent a part of the right scapula. The left scapula seems to be a triradiate bone (Fig. 9b), as usually observed in plesiosaurians (Bardet, Godefroit \& Sciau, 1999). The dorsal ramus is broken and extends posterolaterally. It presents a concave and sharp anterior edge and a convex posterior margin. The posterior ramus is short and incompletely preserved. Its posterior termination is broken. The ventral ramus is not observable. The left coracoid is almost entirely embedded in the matrix and only a small part of the oval facet forming the coracoid's contribution to the humeral glenoid is observable.

Only the left forelimb has been partially preserved (Fig. 9a-c). It appears to be dorsoventrally compressed, but not otherwise distorted. The humerus is gracile and markedly asymmetrical in dorsal or ventral view (Fig. 9c). Its anterior border is nearly straight, slightly convex proximally with a modest distal expansion and its posterior border is very concave because of the distinctive enlargement of its posterodistal part. As a result, the ulnar facet faces posterodistally. The proximal end is partially obscured by matrix and the scapula. The capitulum and the tuberosity are heavily pitted as they served as sites for cartilage attachment. The distal edge of the humerus has two pronounced facets for the radius and ulna and no additional facet.

Proximal parts of the left radius and ulna are preserved (Fig. 9a, c), but the rest of the bones are not preserved. However, the radius and ulna are too incomplete to give more information concerning their general morphology.

A pile of approximately five phalanges are preserved still embedded in the matrix; their original arrangement is thus not known. They have approximately hourglass-shaped outlines in dorsal view.

\section{Analyses}

\section{5.a. Phylogenetic analysis}

In order to develop a hypothesis of the phylogenetic relationships of Microcleidus melusinae among Plesiosauria, a preliminary cladistic analysis was performed using a modified version of the data matrix of Benson, Evans \& Druckenmiller (2012) (see online Supplementary Material S1 available at http: //journals.cambridge.org/geo). A search for the parsimonious trees was performed using PAUPv.4.0b10 (Swofford, 2002). The analysis was run under parsimony setting using the heuristic search option (100 000 replicates), with all characters being unordered and not weighted in any way. From the matrix used by Benson, Evans \& Druckenmiller (2012), coding for Microcleidus spp. was modified for three characters (see online Supplementary Material available at http: //journals.cambridge.org/geo). Yunguisaurus and Pistosaurus were defined as outgroups. The parsimony analysis of the data matrix yielded 42 trees. In the strict consensus, the relationships among plesiosaurians are well resolved (Fig. 10). The trees have a length of 638 steps, a consistency index excluding 


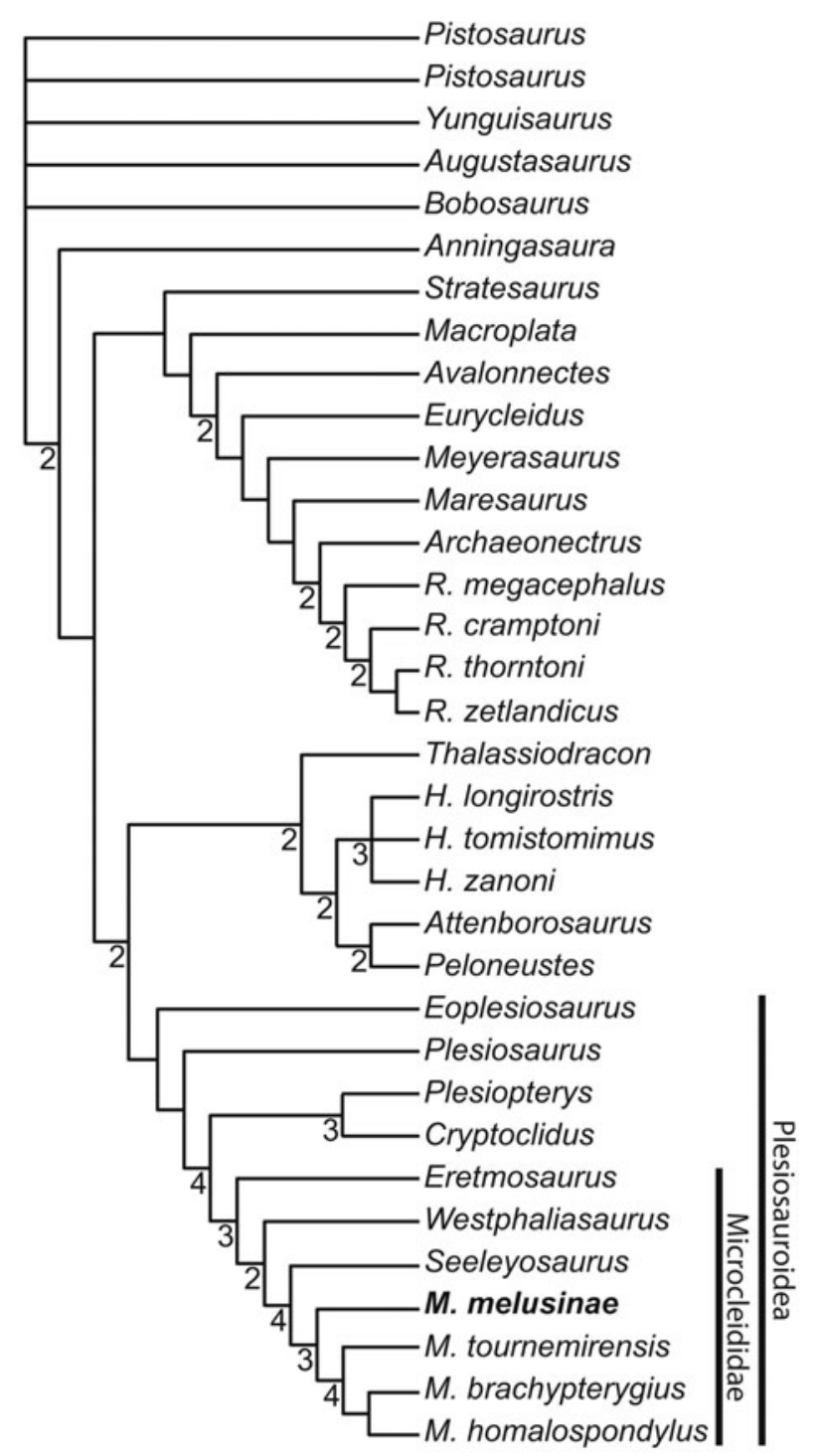

Figure 10. Cladogram (strict consensus of 42 trees) showing the phylogenetic relationships of Microcleidus melusinae. Tree length: 638 . $\mathrm{CI}=0.444$, RI $=0.596$. For character matrix see online Supplementary Material available at http://journals. cambridge.org/geo. Bremer indices are indicated for each node.

uninformative characters of $\mathrm{CI}=0.444$ and a retention index of $\mathrm{RI}=0.5962$.

The topology of the strict consensus is similar to that of Benson, Evans \& Druckenmiller (2012). The family Microcleididae includes the genera Eretmosaurus, Westphaliasaurus, Seeleyosaurus and Microcleidus. In the present analysis, M. melusinae is nested within the monophyletic clade Microcleididae, as a sister taxon of operational taxonomic units (OTUs) belonging to $\mathrm{Mi}$ crocleidus (M. homalospondylus, M. brachypterygius and M. tournemirensis). The family Microcleididae, the Microcleidus clade, as well as the clade including $M$. homalospondylus, $M$. brachypterygius and $M$. tournemirensis are generally well supported (decay in$\operatorname{dex}=$ or $>3$ ).

In the present analysis, the family Microcleididae is supported unambiguously by five synapomorphies: posterior cervical neural spines curved posterodorsally (120.0), broadly separated rib facets of the posterior cervical vertebrae (123.0; also recovered by Benson, Evans \& Druckenmiller, 2012), medial surface of the iliac blade anteroposteriorly concave (178.0; also recovered by Benson, Evans \& Druckenmiller, 2012), preaxial margin of the humerus concave in dorsal or ventral view (188.1; reversal in $M$. tournemirensis and Seeleyosaurus), and prominent flange extends anteriorly from the proximal half of the radius (197.1; also recovered by Benson, Evans \& Druckenmiller, 2012).

The clade grouping the four species of Microcleidus (M. melusinae, M. homalospondylus, M. brachypterygius and M. tournemirensis) is supported by five unambiguous synapomorphies: low ratio of orbit length to temporal fenestra length in dorsal view (3.0), jugal excluded from orbit margin (32.1; corresponding to a synapomorphy of the clade Microcleidus in the analysis of Benson, Evans \& Druckenmiller, 2012), jugal short (33.1; corresponding to a synapomorphy of the clade Microcleidus in the analysis of Benson, Evans \& Druckenmiller, 2012), sagittal crest high and transversally compressed (39.1), and strong anteroposterior constriction at the base of the dorsal neural spines (142.1; corresponding to a synapomorphy of the clade Microcleidus in the analysis of Benson, Evans \& Druckenmiller, 2012).

Following the results of this analysis, and considering that M. melusinae belong to the genus $M i-$ crocleidus, the diagnosis of Microcleidus proposed by Benson, Evans \& Druckenmiller (2012) should be updated:

\section{Microcleidus Watson, 1909}

Emended diagnosis (Benson, Evans \& Druckenmiller, 2012). Microcleidid plesiosauroids possessing a short jugal with anterior termination around the posterior orbital margin, a jugal excluded from the orbit margin, at least a few cervical centra with a lateral longitudinal ridge on lateral surface, anteroposterior constriction at the base of the dorsal neural spines, anterior process of the coracoid long and transversely narrow.

Included taxa. M. homalospondylus, M. brachypterygius, M. tournemirensis, M. melusinae.

It has to be noted that several other phylogenetic analyses including the three species of Microcleidus previously recognized by Benson, Evans \& Druckenmiller (2012) and performed by different authors (Druckenmiller \& Knutsen 2012; M. Evans, unpub. Ph.D. thesis, Univ. Leicester, 2012) recovered them as non-sister taxa, thus suggesting a possible paraphyletic nature of the genus Microcleidus. In the work of Druckenmiller \& Knutsen (2012) no Microcleididae clade was recovered (although they did recover M. homalospondylus and M. tournemirensis as sister taxa), and in the work of M. Evans (unpub. Ph.D. thesis, Univ. 
Leicester, 2012) a monophyletic Microcleididae was still recovered.

\section{5.b. Dissimilarity analysis}

Dissimilarity values were calculated for the four species belonging to the genus Microcleidus and Seeleyosaurus. A dissimilarity matrix was calculated using software provided by R. Daisy (Kaufman \& Rousseeuw, 1990). We used the same cladistic data matrix as that used for the phylogenetic analysis. The original matrix of character codings for the five taxa was used to create a matrix of the pairwise dissimilarities of the five species calculated as the number of character mismatches divided by the number of characters that are not missing or non-applicable (e.g. multistate characters).

Pairwise dissimilarity between all five species is low and varies between 7 and $22 \%$ (see online Supplementary Material S2 available at http:// journals.cambridge.org/geo). The values between M. tournemirensis, $M$. brachypterygius and M. homalospondylus (7-17\%) are comparable to those recovered by Benson, Evans \& Druckenmiller (2012). They are slightly lower than those between M. melusinae and the three other Microcleidus (15$20 \%$ ), but the values between Microcleidus species and Seeleyosaurus are substantially higher (19-22\%). M. melusinae is as dissimilar from M. brachypterygius $(15 \%)$ as the latter is from M. tournemirensis $(17 \%)$ and is only slightly more dissimilar from $M$. homalospondylus (19\%).

\section{Discussion}

\section{6.a. Comparison with other plesiosaurian taxa}

In their analysis, Smith, Araújo \& Mateus (2012) recovered Lusonectes as a sister taxon of Microcleidus sensu lato in a similar position as MNHNL TV434. Unfortunately, the specimen referred to Lusonectes is very fragmentary; however, Lusonectes clearly differs from MNHNL TV434 as its jugal contacts the orbit margin and its ventral parabasisphenoid surface between the posterior interpterygoid vacuities is flat to gently convex.

M. melusinae closely resembles $M$. brachypterygius in that it shares several diagnostic characters with this taxon: an elongate sculptured snout, temporal openings larger than orbits, no jugal-orbit contact, and an absence of an anterior interpterygoid vacuity. Moreover, in both taxa there is an absence of contact between the pterygoid posterior to the posterior interpterygoid vacuity (S. Sachs, pers. com. for M. brachypterygius). However, contra to the three species of Microcleidus (diagnosis of Benson, Evans \& Druckenmiller, 2012), M. melusinae presents anterior cervical centra shorter than high and only two cervical centra bearing a slight longitudinal ridge and no lateral ridge on the anterior cervical centra. Moreover,
M. melusinae possesses an unconstricted snout (contra that observed in $M$. tournemirensis); a slightly longer anterior extension of the jugal than that reported for $M$. brachypterygius (SMNS 51143 and GPIT/477/1/1; Maisch \& Rücklin, 2000; F. Großmann, unpub. Ph.D. thesis, Eberhard-Karls-Universität, Tübingen, 2006, figs 2.6 and 3.2; Großmann, 2007); a shorter participation of the prefrontal to the naris margin than that observed in $M$. brachypterygius (Maisch \& Rücklin, 2000; F. Großmann, unpub. Ph.D. thesis, Eberhard-Karls-Universität, Tübingen, 2006, fig. 3.2); a pineal foramen (contra that reported in $M$. tournemirensis); the rim of the pineal foramen raised dorsally from the surrounding surfaces (contra that observed in $M$. brachypterygius); a frontal excluded from the orbital margin (contra that reported for $M$. tournemirensis and M. homalospondylus); a smooth enamel on the labial surface of the tooth contra $M$. brachypterygius and M. tournemirensis (Maisch \& Rücklin, 2000 reported fine ridges both lingually and labially in $M$. brachypterygius); and 30 postaxial cervical vertebrae (contra that observed in M. homalospondylus and $M$. tournemirensis). It has to be noted that the cervical vertebrae count cannot be used to compare $M$. melusinae with $M$. brachypterygius as the type specimen of $M$. brachypterygius preserves 36 cervical vertebrae (Großmann, 2007), a greater number than that of M. melusinae, whereas the specimen MB.R. 1991 referred to as $M$. brachypterygius by Großmann (2007) possesses a close number of cervicals to that of $M$. melusinae. However, the taxonomic attribution of MB.R. 1991 could necessitate a revision as some anatomical characters seem to differ from the type specimen (e.g. a postaxial margin of the ulna convex in MB.R. 1991 contra that observed in the type specimen of $M$. brachypterygius and the referred specimen SMNS 51143).

Considering the phylogenetic position of the specimen MNHNL TV434 as a sister taxon of the clade comprising M. homalospondylus, M. tournemirensis and $M$. brachypterygius, the low pairwise dissimilarity between these three species and MNHNL TV434, and considering that sufficient anatomical differences exist between them, we place the specimen MNHNL TV434 in the genus Microcleidus and in a new species.

\section{6.b. Palaeobiogeographical zonation of Toarcian plesiosaurians}

The Toarcian plesiosaurians from NW Europe are remarkable in that each species seems restricted to a small geographical area, an observation that led previous authors to suggest a palaeobiogeographical zonation of Toarcian plesiosaurians (Großmann, 2007). All these taxa are, however, not strictly of the same age (Benton \& Taylor, 1984; Urlichs, Wild \& Ziegler, 1994), and it is likely that this apparent diversity reflects a combination of temporal and spatial variations in taxonomic composition. Discussing the palaeogeographical distribution of this fauna thus requires a comparison of specimens that are strictly of the same 
age, i.e. of the same ammonite zone. Within Plesiosauroidea, at least four species (Microcleidus melusinae, Microcleidus brachypterygius, Seeleyosaurus guilelmiimperatoris and Plesiopterys wildii) are from the same ammonite level (elegantulum Subzone or Exaratum Subchronozone, according to different stratigraphic scales in use), which likely represents a maximum duration of $1 \mathrm{Ma}$ (Suan et al. 2008; Boulila et al. 2014). The fossil remains of these four species have been recovered in Germany (Baden Württemberg) and Luxembourg, which are nowadays only $300 \mathrm{~km}$ apart. Moreover, two species of the genus Microcleidus of the same age appear to be present in Germany and Luxembourg and thus show a taxonomical continuity at the genus level but not at the species level. Because no major tectonic shortening phase since the Jurassic has been recognized in this area, it is likely that a similar distance separated these localities at the time of death of these animals. The occurrence of these four different species in a very small area thus tends to demonstrate the high diversity of plesiosaurian taxa during that time, as previously stated for the entire Early Jurassic period (Benson, Evans \& Druckenmiller, 2012).

Acknowledgements. The authors would like to warmly thank Andrea Di Cencio (research associate, MNHNL, Luxembourg) for the determination of ammonites coming from the Bascharage section in the collections of the MNHNL and Lucile Decanter (MNHNL) for the discussion concerning the dissimilarity analysis. The first author also thanks Jocelyn Falconnet (MNHN, Paris) and Guillaume Suan (UCBL, Lyon) for discussions. We warmly thank S. Sachs (Naturkundemuseum Bielefeld), T. Sato (Tokyo Gakugei University), R.A. Otero (Universidad de Chile, Santiago), R. Araújo (Southern Methodist University, Dallas) and two anonymous reviewers for their comments that improved the quality of this manuscript.

\section{Supplementary material}

To view supplementary material for this article, please visit https://doi.org/10.1017/S0016756817000814

\section{References}

ANDREws, C. W. 1910. A Descriptive Catalogue of the Marine Reptiles of the Oxford Clay. Part I. London: British Museum (Natural History), 205 pp.

Andrews, C.W. 1913. A Descriptive Catalogue of the Marine Reptiles of the Oxford Clay. Part II. London: British Museum (Natural History), 206 pp.

Araújo, R., Polcyn, M. J., Lindgren, J., Jacobs, L. L., Schulp, A. S., Mateus, O., Olímpio Gonçalves, A. \& MoraIs, M.-L. 2015. New aristonectine elasmosaurid plesiosaur specimens from the Early Maastrichtian of Angola and comments on paedomorphism in plesiosaurs. Netherlands Journal of Geosciences 94, 93-108.

BARDET, N. 1992. Stratigraphic evidence for the extinction of the ichthyosaurs. Terra Nova 4, 649-56.

Bardet, N., Godefroit, P. \& Sciau, J. 1999. A new elasmosaurid plesiosaur from the Lower Jurassic of southern France. Palaeontology 42, 927-52.
Bardet, N., Pereda Suberbiola, X. \& Ruiz-Omeñaca, J. I. 2008. Mesozoic marine reptiles from the Iberian Peninsula. Geo-Temas 10, 1245-48.

Benson, R. B. J., Bates, K. T., Johnson, M. R. \& Withers, P. J. 2011. Cranial anatomy of Thalassiodracon hawkinsii (Reptilia, Plesiosauria) from the Early Jurassic of Somerset, United Kingdom. Journal of Vertebrate Paleontology 31, 562-74.

Benson, R. B., Butler, R. J., Lindgren, J. \& Smith, A. S. 2009. Mesozoic marine tetrapod diversity: mass extinctions and temporal heterogeneity in geological megabiases affecting vertebrates. Proceedings of the Royal Society of London B: Biological Sciences 277, 829-34.

Benson, R. B. J., Evans, M. \& Druckenmiller, P. S. 2012. High diversity, low disparity and small body size in plesiosaurs (Reptilia, Sauropterygia) from the Triassic-Jurassic boundary. PLOS ONE 7, e31838. doi: 10.1371/journal.pone.0031838.

Benson, R. B. J., Evans, M. \& Taylor, M. A. 2015. The anatomy of Stratesaurus (Reptilia, Plesiosauria) from the Lowermost Jurassic of Somerset, United Kingdom. Journal of Vertebrate Paleontology 35, e933739. doi: 10.1080/02724634.2014.933739.

Benton, M. J. \& Taylor, M. A. 1984. Marine reptiles from the Upper Lias (Lower Toarcian, Lower Jurassic) of the Yorkshire coast. Proceedings of the Yorkshire Geological Society 44, 399-429.

Blainville, H. D. DE. 1835. Description de quelques espèces de reptiles de la Californie, précédée de l'analyse d'un système général d'Erpétologie et d'Amphibiologie. Nouvelles Annales du Muséum (national) d'Histoire Naturelle, Paris (serie 3) 4, 233-96.

Boulila, S., Galbrun, B., Huret, E., Hinnov, L. A., Rouget, I., Gardin, S. \& Bartolini, A. 2014. Astronomical calibration of the Toarcian Stage: implications for sequence stratigraphy and duration of the early Toarcian OAE. Earth and Planetary Science Letters 386, 98-111.

Brown, D. S. 1981. The English Upper Jurassic Plesiosauroidea (Reptilia) and a review of the phylogeny and classification of the Plesiosauria. Bulletin of the British $\mathrm{Mu}$ seum (Natural History) Geology 35, 253-347.

Brown, D. S., VincENT, P. \& BARDET, N. 2013. Osteological redescription of the skull of Microcleidus homalospondylus (Sauropterygia, Plesiosauria) from the Lower Jurassic of England. Journal of Paleontology 87, 537-49.

Cheng, Y.-N., Sato, T., Wu, X.-C. \& Li, C. 2006. First complete pistosauroid from the Triassic of China. Journal of Vertebrate Paleontology 26, 501-4.

DAmes, W. 1895. Die Plesiosaurier der Süddeutschen Liasformation. Abhandlungen der Königlich Preussischen Akademie der Wissenschaften zu Berlin 1895, 1-81.

Delsate, D. 1997a. Actinoptérygiens du Toarcien inférieur du Grand Duché de Luxembourg. Présence de Leptolepis normandica NYBELIN 1962 (Téléostéen) avec otolithes in situ. In Notes Paléontologiques et Biostratigraphiques sur le Grand-Duché de Luxembourg et les Régions Voisines (eds P. L. Maubeuge \& D. Delsate), pp. 105-30. Travaux scientifiques du Musée d'histoire naturelle de Luxembourg, 27.

Delsate, D. 1997b. Chondrichthyens mésozoïques du Luxembourg. Compléments. In Notes Paléontologiques et Biostratigraphiques sur le Grand-Duché de Luxembourg et les Régions Voisines (eds P. L. Maubeuge \& D. Delsate), pp. 53-79. Travaux Scientifiques du Musée d'histoire naturelle de Luxembourg, 27.

Delsate, D. 1999a. L'ichthyofaune du Toarcien luxembourgeois. Cadre général et catalogue statistique. Travaux 
Scientifiques du Musée national d'histoire naturelle de Luxembourg 30, 1-101.

Delsate, D. 1999b. Haasichthys michelsi, nov. gen., nov. sp., un nouveau Pachycormiforme (Osteichthyes, Actinopterygii) du Toarcien inférieur (Jurassique) luxembourgeois. Travaux Scientifiques du Musée national d'histoire naturelle de Luxembourg 32, 87-140.

Delsate, D. 1999c. Un Pholidophoridae nouveau (Osteichthyes, Actinopterygii) du Toarcien (Jurassique inférieur) luxembourgeois. Travaux Scientifiques $d u$ Musée national d'histoire naturelle de Luxembourg 32, 141-205.

Delsate, D. 2003. Une nouvelle faune de poissons et requins toarciens du sud du Luxembourg (Dudelange) et de l'Allemagne (Schömberg). Bulletin de l'Académie Lorraine des Sciences 42, 1-4.

Delsate, D. \& Godefroit, P. 1995. Chondrichthyens du Toarcien inférieur d'Aubange (Lorraine belge). In Elasmobranches et Stratigraphie (eds J. Herman \& H. Van Waes), pp. 23-43. Brussels: Belgian Geological Survey, Professional Paper 278.

Delsate, D. \& CANDONi, L. 2001. Description de nouveaux morphotypes dentaires de Batomorphii toarciens (Jurassique inférieur) du Bassin de Paris: Archaeobatidae nov. fam. Bulletin de la Société Nationale luxembourgeoise 102, 131-43.

Delsate, D. \& Weis, R. 2010. La Couche à Crassum (Toarcien moyen) au Luxembourg: stratigraphie et faunes de la coupe de Dudelange-Zoufftgen. In Le Jurassique Inférieur et Moyen au Luxembourg - Nouvelles Données Paléontologiques et Biostratigraphiques (eds R. Weis \& S. Guérin-Franiatte), pp. 35-62. Ferrantia, Musée national d'histoire naturelle, Luxembourg, 62.

DRUCKENMILLER, P. S. 2002. Osteology of a new plesiosaur from the Lower Cretaceous (Albian) Thermopolis Shale of Montana. Journal of Vertebrate Paleontology 22, 2942.

Druckenmiller, P. S. \& Knutsen, E. M. 2012. Phylogenetic relationships of Upper Jurassic (middle Volgian) plesiosaurians (Reptilia: Sauropterygia) from the Agardhfjellet Formation of central Spitsbergen, Norway. Norwegian Journal of Geology 92, 277-84.

Druckenmiller, P. S. \& Russell, A. P. 2008. A phylogeny of Plesiosauria (Sauropterygia) and its bearing on the systematic status of Leptocleidus Andrews, 1922. Zootaxa 1863, 1-120.

Fuchs, D. \& WeIs, R. 2008. Taxonomy, morphology and phylogeny of Lower Jurassic loligosepiid coleoids (Cephalopoda). Neues Jahrbuch für Geologie und Paläontologie 249, 93-112.

Gasparini, Z. \& FERnANDEZ, M. 1996. Biogeographic affinities of the Jurassic marine reptile fauna of South America. In Advances in Jurassic Research - Georesearch Forum, Vol. 1-2 (ed. A. Riccardi), pp. 443-50. Switzerland: TransTec Publications.

Gasparini, Z., SAlgado, L. \& CASAdio, S. 2003. Maastrichtian plesiosaurs from northern Patagonia. Cretaceous Research 24, 157-70.

GodefroIT, P. 1994. Les reptiles marins du Toarcien (Jurassique inférieur) belgo-luxembourgeois. Geological Survey of Belgium 39, 1-98.

Grossmann, F. 2007. The taxonomic and phylogenetic position of the Plesiosauroidea from the Lower Jurassic Posidonia shale of south-west Germany. Palaeontology 50, 545-64.

Guérin-Franiatte, S., Maquil, R. \& Münzberger, P. 2010. Le Toarcien au Grand-Duché de Luxembourg: biostratigraphie dans la région de Belvaux. In Le Jurassique Inférieur et Moyen au Luxembourg - Nouvelles Données Paléontologiques et Biostratigraphiques (eds R. Weis \& S. Guérin-Franiatte), pp. 19-34. Ferrantia, Musée national d'histoire naturelle, Luxembourg, 62.

Hanzo, M. 1978. A propos de nodules carbonatés du Toarcien inférieur de la région de Bettembourg (GrandDuché de Luxembourg). 103ème Congrès national des Sociétés savantes, Nancy, Sciences 4, 343-9.

Hanzo, M. 1979. Milieu de dépôt et évolution diagénétique des argilites toarciennes d'après l'étude de nodules carbonatés des « schistes carton » de Bettembourg (Grand Duché de Luxembourg). Sciences de la Terre 23, 45-59.

Henrotay, M., Marques, D., Paicheler, J.-C., Gall, J.-C. \& NeL, A. 1998. Le Toarcien inférieur des régions de Bascharage et de Bettembourg (Grand-Duché du Luxembourg): évidences paléontologiques et sédimentologiques d'environnements restreints proches de l'émersion. Geodiversitas 20, 263-84.

Hermoso, M., Delsate, D., Baudin, F., Le Callonnec, L., Minoletti, F., Renard, M. \& Faber, A. 2014. Record of Early Toarcian carbon cycle perturbations in a nearshore environment: the Bascharage section (easternmost Paris Basin). Solid Earth 5, 793-804.

Huene, F. von. 1923. Ein neuer Plesiosaurier aus dem oberen Lias Württembergs. Jahreshefte des Vereins für vaterländische Naturkunde in Württemberg 79, 3-23.

Kaufman, L. \& Rousseeuw, P. J. 1990. Finding Groups in Data: An Introduction to Cluster Analysis. New York: Wiley.

KEAR, B. P. 2012. A revision of Australia's Jurassic plesiosaurs. Palaeontology 55, 1125-38.

Ketchum, H. F. \& Benson, R. B. J. 2011. The cranial anatomy and taxonomy of Peloneustes philarchus (Sauropterygia, Pliosauridae) from the Peterborough member (Callovian, Middle Jurassic) of the United Kingdom. Palaeontology 54, 639-65.

Maisch, M. W. 2008. Revision der Gattung Stenopterygius Jaekel, 1904 emend. von Huene, 1922 (Reptilia: Ichthyosauria) aus dem unteren Jura Westeuropas. Palaeodiversity 1, 227-71.

Maisch, M. W. \& RüCKLIN, M. 2000. Cranial osteology of the sauropterygian Plesiosaurus brachypterygius from the Lower Toarcian of Germany. Palaeontology 43, 29 40.

MartiLl, D. M. 1993. Soupy substrates: a medium for the exceptional preservation of ichthyosaurs of the Posidonia Shale (Lower Jurassic) of Germany. Kaupia 2, 7797.

O’Keefe, R. F. 2001. A cladistic analysis and taxonomic revision of the Plesiosauria (Reptilia: Sauropterygia). Acta Zoologica Fennica 213, 1-63.

Owen, R. 1860. On the orders of fossil and recent Reptilia, and their distribution through time. Report of the British Association for the Advancement of Science 1859, 15366.

Owen, R. 1865. A monograph on the fossil Reptilia of the Liassic formations. Pt. 1. Monograph for the Palaeontographical Society 17, 1-40.

Page, K. 2003. The Lower Jurassic of Europe: its subdivision and correlation. Geological Survey of Denmark and Greenland Bulletin 1, 23-59.

Plet, C., Grice, K., Pages, A., Ruebsam, W., Coolen, M. \& SCHWARK, L. 2016. Microbially-mediated fossilbearing carbonate concretions and their significance for palaeoenvironmental reconstructions: a multi-proxy organic and inorganic geochemical appraisal. Chemical Geology 426, 95-108. 
Rees, J. \& Bonde, N. 1999. Plesiosaur remains from the Early Jurassic Hasle Formation, Bornholm, Denmark. In Secondary Adaptation to Life in Water, Copenhagen, Abstracts Volume (eds E. Hoch \& A. M. Brantsen), p. 70. Copenhagen: Geologisk Museum.

Rieppel, O., SANDER, P. M. \& Storrs, G. W. 2002. The skull of the pistosaur Augustasaurus from the Middle Triassic of northwestern Nevada. Journal of Vertebrate Paleontology 22, 577-92.

Sachs, S., Hornung, J. J., Lierl, H.-J. \& Kear, B. P. 2016. Plesiosaurian fossils from Baltic glacial erratics: evidence of Early Jurassic marine amniotes from the southwestern margin of Fennoscandia. In Mesozoic Biotas of Scandinavia and its Arctic Territories (eds B. P. Kear, J. Lindgren, J. H. Hurum, J. Milàn, \& V. Vajda), pp. 149-63. Geological Society of London, Special Publication no. 434

Sachs, S., Schubert, S. \& Kear, B. P. 2014. Mitteilung über ein neues Skelett eines Plesiosauriers (Reptilia: Sauropterygia) aus dem Oberen Pliensbachium (Unterjura) von Bielefeld, Nordwestdeutschland Berichte Naturwissenschaftlicher Verein für Bielefeld und Umgegend 52, 26-35.

SchwermanN, L. \& SANDER, P. M. 2011. Osteologie und phylogenie von Westphaliasaurus simonensii: ein neuer Plesiosauride (Sauropterygia) aus dem Unteren Jura (Pliensbachium) von Sommersell (Kreis Höxter), Nordrhein-Westfalen, Deutschland. Geologie und Paläontologie in Westfalen 79, 1-56.

Sennikov, A. G. \& Arkhangelsky, M. S. 2010. On a typical Jurassic sauropterygian from the Upper Triassic of Wilczek Land (Franz Josef Land, Arctic Russia). Paleontological Journal 44, 567-72.

Sмith, A. S. 2008. Plesiosaurs from the Pliensbachian (Lower Jurassic) of Bornholm, Denmark. Journal of Vertebrate Paleontology 28, 1213-7.

Smith, A. S., Araúso, R. \& Mateus, O. 2012. A new plesiosauroid from the Toarcian (Lower Jurassic) of Alhadas, Portugal. Acta Palaeontologica Polonica 57, 257-66.

Smith, A. S. \& DyKe, G. J. 2008. The skull of the giant predatory pliosaur Rhomaleosaurus cramptoni: implications for plesiosaur phylogenetics. Naturwissenschaften $\mathbf{9 5}$, 975-80.

Storrs, G. W. 1991. Anatomy and relationships of Corosaurus alcovensis (Diapsida: Sauropterygia) and the Triassic Alcova Limestone of Wyoming. Bulletin of the Peabody Museum of Natural History, Yale University 44, 1-151.

StorRs, G. W. 1997. Morphological and taxonomic clarification of the genus Plesiosaurus. In Ancient Marine Reptiles (eds J. M. Callaway \& C. L. Nicholls), pp. 145-90. San Diego: Academic Press.

Storrs, G. W. \& TAYLOR, M. A. 1996. Cranial anatomy of a new plesiosaur genus from the lowermost Lias (Rhaetian/Hettangian) of Street, Somerset, England. Journal of Vertebrate Paleontology 16, 403-20.

Suan, G., Mattioli, E., Pittet, B., Mailliot, S. \& LECUYER, C. 2008. Evidence for major environmental perturbation prior to and during the Toarcian (Early Jurassic) oceanic anoxic event from the Lusitanian Basin, Portugal. Paleoceanography 23, PA1202. doi: 10.1029/2007PA001459.

Sues, H.-D. 1987. Postcranial skeleton of Pistosaurus and interrelationships of the Sauropterygia (Diap- sida). Zoological Journal of the Linnean Society 90, 109-31.

Swofford, D. L. 2002. PAUP*: Phylogenetic Analysis Using Parsimony (* and other methods) for Macintosh. Version 4.0b10. Sunderland, Massachusetts: Sinauer Associates.

Szwedo, J. 2011. The Coleorrhyncha (Insecta: Hemiptera) of the European Jurassic, with a description of a new genus from the Toarcian of Luxembourg. Volumina Jurassica 9, 3-20.

TAYLOR, M. A. 1992. Functional anatomy of the head of the large aquatic predator Rhomaleosaurus zetlandicus (Plesiosauria, Reptilia) from the Toarcian (Lower Jurassic) of Yorkshire, England. Philosophical Transactions of the Royal Society of London. Series B: Biological Sciences 335, 247-80.

Taylor, M. A. \& Cruickshank, A. R. 1993a. A plesiosaur from the Linksfield erratic (Rhaetian, upper Triassic) near Elgin, Morayshire. Scottish Journal of Geology 29, 191-6.

TaYlor, M. A. \& Cruickshank, A. R. I. 1993b. Cranial anatomy and functional morphology of Pliosaurus brachyspondylus (Reptilia: Plesiosauria) from the Upper Jurassic of Westbury, Wiltshire. Philosophical Transactions of the Royal Society of London. Series B: Biological Sciences 341, 399-418.

Thies, D. 1992. Die Erhaltung von Fischen in den GeodenLagen des nordwestdeutschen Posidonienschiefers. Kaupia: Darmstadter Beiträge zur Naturgeschichte 1, 11-21.

Thulborn, R. A. \& WARREN, A. 1980. Early Jurassic plesiosaurs from Australia. Nature 285, 224-5.

Urlichs, M., WILD, R. \& ZIEgleR, B. 1994. Der Posidonien-Schiefer des unteren Juras und seine Fossilien, Stuttgarter Beiträge zur Naturkunde, Serie C 36, $1-95$.

Vincent, P., Bardet, N., Suberbiola, X. P., Bouya, B., Amaghzaz, M. \& Meslouh, S. 2011. Zarafasaura oceanis, a new elasmosaurid (Reptilia: Sauropterygia) from the Maastrichtian Phosphates of Morocco and the palaeobiogeography of latest Cretaceous plesiosaurs. Gondwana Research 19, 1062-73.

Vincent, P., Bardet, N. \& Mattioli, E. 2013. A new pliosaurid from the Pliensbachian (Early Jurassic) of Normandy (Northern France). Acta Palaeontologica Polonica 58, 471-85.

Vincent, P. \& Benson, R. B. J. 2012. Anningasaura, a basal plesiosaurian (Reptilia, Plesiosauria) from the Lower Jurassic of Lyme Regis, United Kingdom. Journal of Vertebrate Paleontology 32, 1049-63.

Vincent, P., Martin, J. E., Fischer, V., Suan, G., Khalloufi, B., Sucheras-Marx, B., Lena, A., JanNeau, K., Rousselle, B. \& Rulleau, L. 2013. Marine vertebrate remains from the Toarcian-Aalenian succession of southern Beaujolais, Rhône, France. Geological Magazine 150, 822-34.

Watson, D. M. S. 1909. IV. A preliminary note on two new genera of upper Liassic plesiosaurs. Memoirs and Proceedings of the Manchester Literary and Philosophical Society 54 (4), 1-28.

Welles, S. P. 1943. Elasmosaurid plesiosaurs with description of new material from California and Colorado. Memoirs of the University of California 13, 125-254. 